\title{
Relations between hinterland and foreland shortening: Sevier orogeny, central North American Cordillera
}

\author{
Wanda J. Taylor ${ }^{1}$, John M. Bartley², Mark W. Martin ${ }^{3}$, John W. Geissman ${ }^{4}$, \\ J. Douglas Walker ${ }^{5}$, Phillip A. Armstrong ${ }^{6}$, and Joan E. Fryxell ${ }^{7}$
}

\begin{abstract}
The tectonic relations between foreland and hinterland deformation in noncollisional orogens are critical to understanding the overall development of orogens. The classic central Cordilleran foreland fold-and-thrust belt in the United States (Late Jurassic to early Tertiary Sevier belt) and the more internal zones to the west (central Nevada thrust belt) provide data critical to understanding the development of internal and external parts of orogens. The Garden Valley thrust system, part of the central Nevada thrust belt, crops out in south-central Nevada within a region generally considered to be the hinterland of the Jurassic to Eocene Sevier thrust belt. The thrust system consists of at least four principal thrust plates composed of strata as young as Pennsylvanian in age that are unconformably overlain by rocks as old as Oligocene, suggesting that contraction occurred between those times. New $\mathrm{U} / \mathrm{Pb}$ dates on intrusions that postdate contraction, combined with new paleomagnetic data showing significant tilting of one area prior to intrusion, suggest that regionally these thrusts were active before $\sim 85-100 \mathrm{Ma}$. The thrust faults are characterized by long, relatively steeply dipping ramps and associated folds that are broad and open to close, upright and overturned. Although now fragmented by Cenozoic crustal extension, individual thrusts can be correlated from range to range for tens to hundreds of kilometers along strike. We correlate the structurally lowest thrust of the Garden Valley thrust system, the Golden Gate-Mount Irish thrust, southward with the Gass Peak thrust of southern Nevada. This correlation carries the following regional implications. At least some of the slip across Jurassic to mid-Cretaceous foreland thrusts in southern Nevada continues northward along the central Nevada thrust belt rather than northeastward into Utah. This continuation is consistent with age relations, which indicate that thrusts in the type Sevier belt in central Utah are synchronous with or younger than the youngest thrusts in southern Nevada. This in turn implies that geometrically similar Sevier belt thrusts in Utah must die out southward before they reach Nevada, that slip along the southern Nevada thrusts is partitioned
\end{abstract}

\footnotetext{
'Department of Geoscience, University of Nevada, Las Vegas.

${ }^{2}$ Department of Geology \& Geophysics, University of Utah, Salt Lake City.

${ }^{3} \mathrm{U}-\mathrm{Pb}$ Geochronology Laboratory, Massachusetts Institute of Technology, Cambridge.

${ }^{4}$ Department of Earth \& Planetary Sciences, University of New Mexico, Albuquerque.

${ }^{5}$ Isotope Geochemistry Laboratory, University of Kansas, Lawrence.

'Department of Geological Sciences, California State University,

Fullerton.

${ }^{7}$ Department of Geological Sciences, California State University, San Bernardino.
}

Copyright 2000 by the American Geophysical Union

Paper number 1999TC001141.

0278-7407/00/1999TC001141\$12.00 between central Nevada and Utah thrusts, or that the Utah thrusts persist into southeastern Nevada but are located east of the longitude of the central Nevada thrust belt. As a result of overall cratonward migration of thrusting, the central Nevada thrust belt probably formed the Cordilleran foreland fold-thrust belt early in the shortening event but later lay in the hinterland of the Sevier foldthrust belt of Idaho-Wyoming-Utah.

\section{Introduction}

Many investigations in the North American Cordillera and the Andes focus interest on tectonic relations between deformation of internal and external zones of noncollisional orogens [e.g., Armstrong, 1982; Jordan et al., 1983; Sheffels, 1990; Allmendinger et al., 1990; Allmendinger, 1992; Schmitz, 1994; Kley, 1996; Lamb and Hoke, 1997; Okaya et al., 1997; Wells, 1997]. Relations between the Late Jurassic to early Tertiary Sevier foreland thrust belt in Idaho, Wyoming, and Utah and the more internal zones of the Cordilleran orogen play a central role in evolving thought regarding foreland-hinterland relations [Armstrong, 1968; Fleck, 1970; Allmendinger and Jordan, 1984; Heller et al., 1986; Lawton, 1986; Miller et al., 1988; Wannamaker et al., 1997]. The area reaching from western Utah to central Nevada and northward into southern Idaho has long been regarded as the hinterland of the Sevier thrust belt [e.g., Misch, 1960]. Interpretations of the structural style of the hinterland and its tectonic relationship to the foreland thrust belt vary widely. Armstrong [1968, 1972, 1982] concluded that during thin-skinned foreland thrusting the hinterland underwent intense ductile deformation at middle to lower crustal depths but mild upper crustal deformation. This interpretation has been adopted by many others [e.g., Jordan et al., 1983; Miller and Gans, 1989, 1990; Nelson, 1990]. Folds, low-angle faults, and tectonic rock fabrics recognized in the region west of the frontal Sevier thrusts [Nolan, 1935, 1962; Misch, 1960; Cebull, 1967; Quinlivan et al., 1974; Hose and Blake, 1976; Tschanz and Pampeyan, 1970] have been interpreted either to affect only deeper structural levels [e.g., Miller et al., 1988; Miller and Gans, 1989], to record only minor crustal shortening [Allmendinger and Jordan, 1984; Miller and Hoisch, 1992; Miller and Lush, 1994], or to have formed during subsequent Mesozoic and/or Cenozoic crustal extension [e.g., Moores et al., 1968; Armstrong, 1972]. In contrast, syntheses by Speed [1983] and Speed et al. [1988] included significant contraction along a "Eureka thrust belt" in central Nevada, but the nature, magnitude, and tectonic significance of this thrust belt were largely unspecified. Resolution of the uncertainties in age and kinematics of hinterland deformation also is necessary to future improvements in kinematic synthesis of Cordilleran subduction-related orogeny [e.g., Bird, 1998].

Major problems in defining the Sevier hinterland and in elucidating its structural history reflect difficulties in distinguishing 
among different ages and kinematic histories of structures (e.g., compare Misch [1960] and Cebull [1967] with Moores et al. [1968] and Armstrong [1972, 1982] see also Smith et al. [1993] and Lawton et al. [1994]) and in unraveling their overprinting relations. However, field mapping and isotopic dating [e.g., Allmendinger and Jordan, 1984; Lee et al., 1987; Fryxell, 1988; Bartley and Gleason, 1990; Wells et al., 1990; Taylor and Bartley, 1992; McGrew, 1993], combined with better understanding of the structural geometries of contractional and extensional belts [e.g., Boyer and Elliott, 1982; Wernicke and Burchfiel, 1982; Davis et al., 1983; Woodward et al., 1985; Wernicke et al., 1988a], now permit clearer distinctions between structures related to crustal extension and contraction. Geologic mapping indicates that thrusts with significant offset crop out in central and eastern Nevada [e.g., Nolan, 1935; Tschanz and Pampeyan, 1970; Fryxell, 1988; Bartley and Gleason, 1990; Armstrong and Bartley, 1993; Taylor et al., 1993; Dobbs et al., 1993]. These studies, including new field observations reported here, permit us to refine the structural development of a significant part of the Sevier hinterland and to evaluate the tectonic relationship between the hinterland and the classic Sevier foreland thrust belt (Figure 1).

Defined by Bartley and Gleason [1990], the Garden Valley thrust system is part of the central Nevada thrust belt and comprises contractional structures exposed in several ranges southeast of Railroad Valley (Figures 1 and 2). The purposes of this paper are (1) to describe contractional structures of the Garden Valley thrust system which were previously not well understood, (2) to correlate these contractional structures within the central Nevada thrust belt and regionally, and (3) to interpret the relationship between the central Nevada thrust belt and the Sevier orogenic belt. Geologic mapping at 1:24,000 and 1:12,000 scales of the Golden Gate Range, Worthington Mountains, Timpahute Range, and Mount Irish plus paleomagnetic data and U-Pb geochronology [also see Martin, 1987; Armstrong, 1991] are integrated with published work [e.g., Tschanz and Pampeyan, 1970; Burchfiel et al., 1983; Wernicke et al., 1988b; Bartley and Gleason, 1990; Jayko, 1990] to characterize the structural style of the thrust belt, correlate structures along strike, and reevaluate the regional-tectonic framework for Mesozoic foreland thrusting in this section of the Cordilleran orogen.

\section{Regional Geologic Setting}

The central Nevada thrust belt is a north trending belt of contractional structures, continuous except where interrupted by Cenozoic normal faults, that can be traced for $>400 \mathrm{~km}$ northward from the Pahranagat shear zone $\left(-37^{\circ} 14 \mathrm{~N}\right)$ in southern Nevada to the northern Adobe Range $\left(\sim 41^{\circ} 19 \mathrm{~N}\right)$. At its southern end the central Nevada thrust belt projects toward thrusts and folds of the Sevier orogenic belt in southem Nevada (Figure 1) [Armstrong, 1968]. Part of the central Nevada thrust belt previously was identified as part of the Eureka belt in the area north and northwest of Railroad Valley [Speed, 1983; Speed et al., 1988] and the Garden Valley thrust system to the southeast of Railroad Valley [Bartley and Gleason, 1990; Armstrong and Bartley, 1993]. Although no specific structure has been correlated across Railroad Valley, contractional structures located northwest and southeast of Railroad Valley lie approximately along strike of each other and have comparable styles and compatible timing brackets. Therefore the existence of a single, once-continuous fold-thrust belt seems clear.

The Garden Valley thrust system comprises the Sawmill, Schofield Canyon, Rimrock-Freiberg-Lincoln, and Golden Gate-
Mount Irish thrusts and associated folds. The system is characterized by thrusts with long, relatively steeply dipping ramps and open to close folds that are typically upright in upper plates of thrusts; overturned folds occur mainly in thrust footwalls. Individual thrust faults can be correlated from range to range for tens to hundreds of kilometers along strike.

Within many of the range-scale fault blocks where the thrusts are exposed (i.e., the Timpahute Range-Worthington Mountains, and Mount Irish-Golden Gate Ranges), extensional deformation is small in magnitude but locally intricate in geometry (e.g., Figure 2). Such Cenozoic extensional structures, including $\sim \mathrm{N}-\mathrm{S}$ striking normal faults and E-W striking faults, variably overprint the Garden Valley thrust system (Figure 2). The Golden Gate Range-Mount Irish Cenozoic normal-fault block is separated from the Worthington Mountains-Timpahute Range block by large-displacement north striking normal faults. Tertiary volcanic rocks exposed between the southern Worthington Mountains and Timpahute Range (Figure 2) are cut by numerous normal faults that have been active episodically since $24 \mathrm{Ma}$ [Taylor, 1992]. East striking Cenozoic normal faults define the southem boundary of this more extended region with the east trending Timpahute Range fault block. An east striking fault zone also separates Paleozoic strata of the Timpahute Range block from more extended Tertiary volcanic rocks on its south (Figure 2).

\section{Stratigraphy}

\subsection{Relevant Stratigraphy}

Although comprehensive stratigraphic descriptions lie outside the scope of this work [see Kellogg, 1963; Reso, 1963; Tschanz and Pampeyan, 1970; Best and Grant, 1987; Best et al., 1989; Hurtubise, 1989; Taylor, 1990; Best and Christiansen, 1991; Hurtubise and du Bray, 1992], differences in stratigraphic relations of Paleozoic and Cenozoic rocks from one thrust plate to the next are important to structural correlation. Therefore, we briefly introduce the regional stratigraphy.

The Garden Valley thrust system deforms strata typical of the southern Cordilleran continental margin that range from Late Precambrian to Pennsylvanian age [Kellogg, 1963; Stewart et al., 1977]. The strata are dominantly clean and silty carbonate rocks with subordinate calcite- and silica-cemented quartz sandstone, siltstone, and shale (Figure 3 ). This well-described miogeoclinal sequence permitted mapping and correlation of the same formations throughout most of the area. Cenozoic rocks that overlie the thrust system are mostly Tertiary ash flow tuffs with subordinate lava flows, freshwater limestone, and continental siliciclastic rocks of both Tertiary and Quaternary ages (Figure 3).

Because a regional decollement is not exposed, the oldest rocks exposed in the thrust plates provide the only information about the depth of a regional thrust decollement. In the Grant and Quinn Canyon Ranges the Lower Cambrian Prospect Mountain Quartzite is exposed in thrust plates. The oldest rocks exposed in other ranges are Middle Cambrian or younger. Therefore a regional decollement would have to lie below the Lower Cambrian rocks carried by the Garden Valley thrust system.

\subsection{Sub-Tertiary Unconformity}

The unconformity beneath Tertiary strata served as the principal datum for reconstructing cross sections to their preextensional geometry (Figure 4). The outcrop pattern and angularity of the subTertiary unconformity indicates that the unconformity ascends 


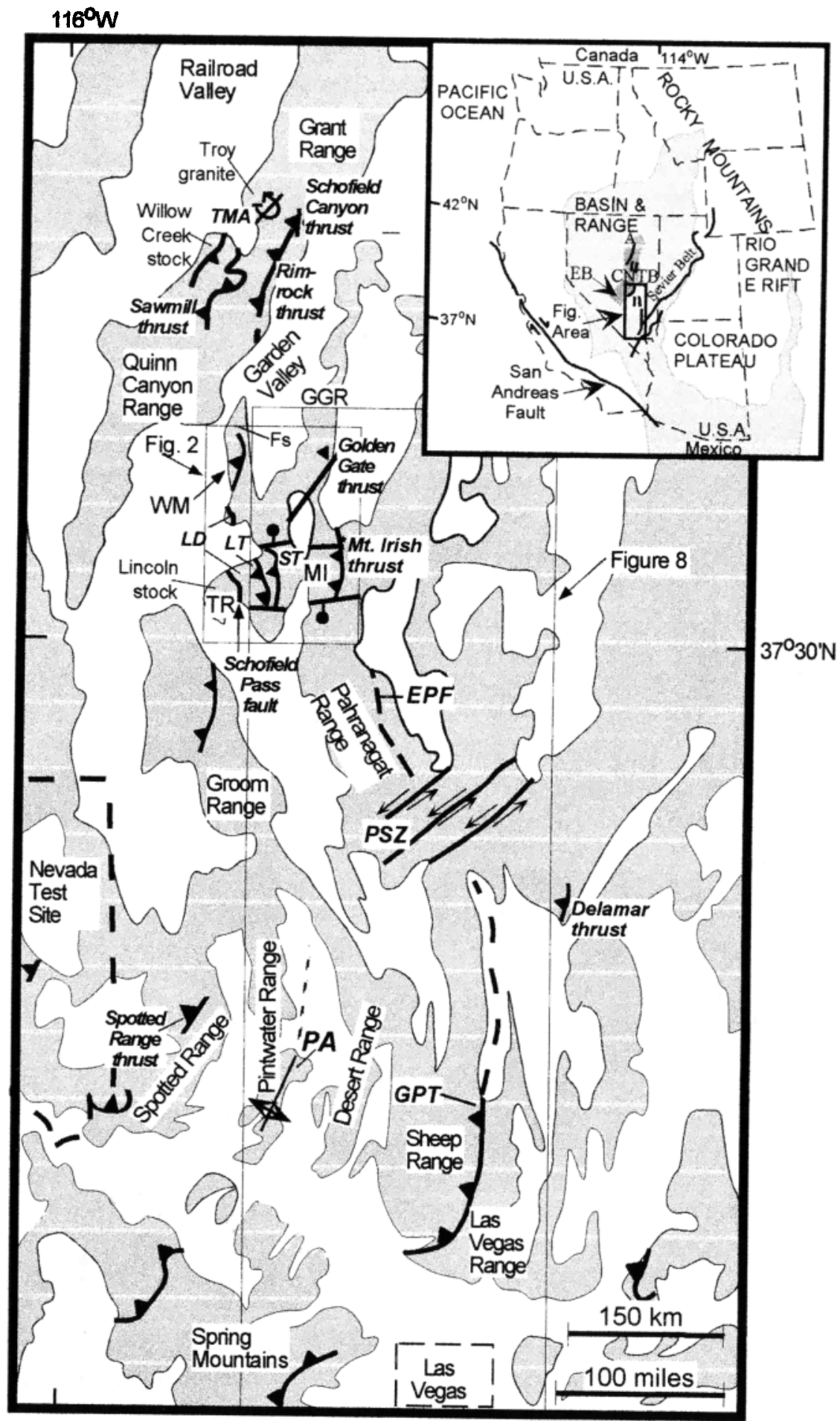

Figure 1. Locations and names of ranges (stippled), valleys (white) and major contractional structures that are discussed in the text, including the Garden Valley thrust system. Box within the inset shows the location of the larger map. A, northern Adobe Range; CNTB, central Nevada thrust belt; EB, Eureka thrust belt [after Speed et al., 1988]; EPF, East Pahranagat fault; Fs, Freiberg stock; GGR, Golden Gate Range; GPT, Gass Peak thrust; LCTS, location of Last Chance thrust system; $L D$, Lincoln duplex; $L T$, Lincoln thrust; MI, Mount Irish; MIT, Mount Irish thrust; $P A$, Pintwater anticline; PSZ, Pahranagat Shear Zone; ST, Schofield thrust; TMA, Timber Mountain anticline; TR, Timpahute Range; and WM, Worthington Mountains. 


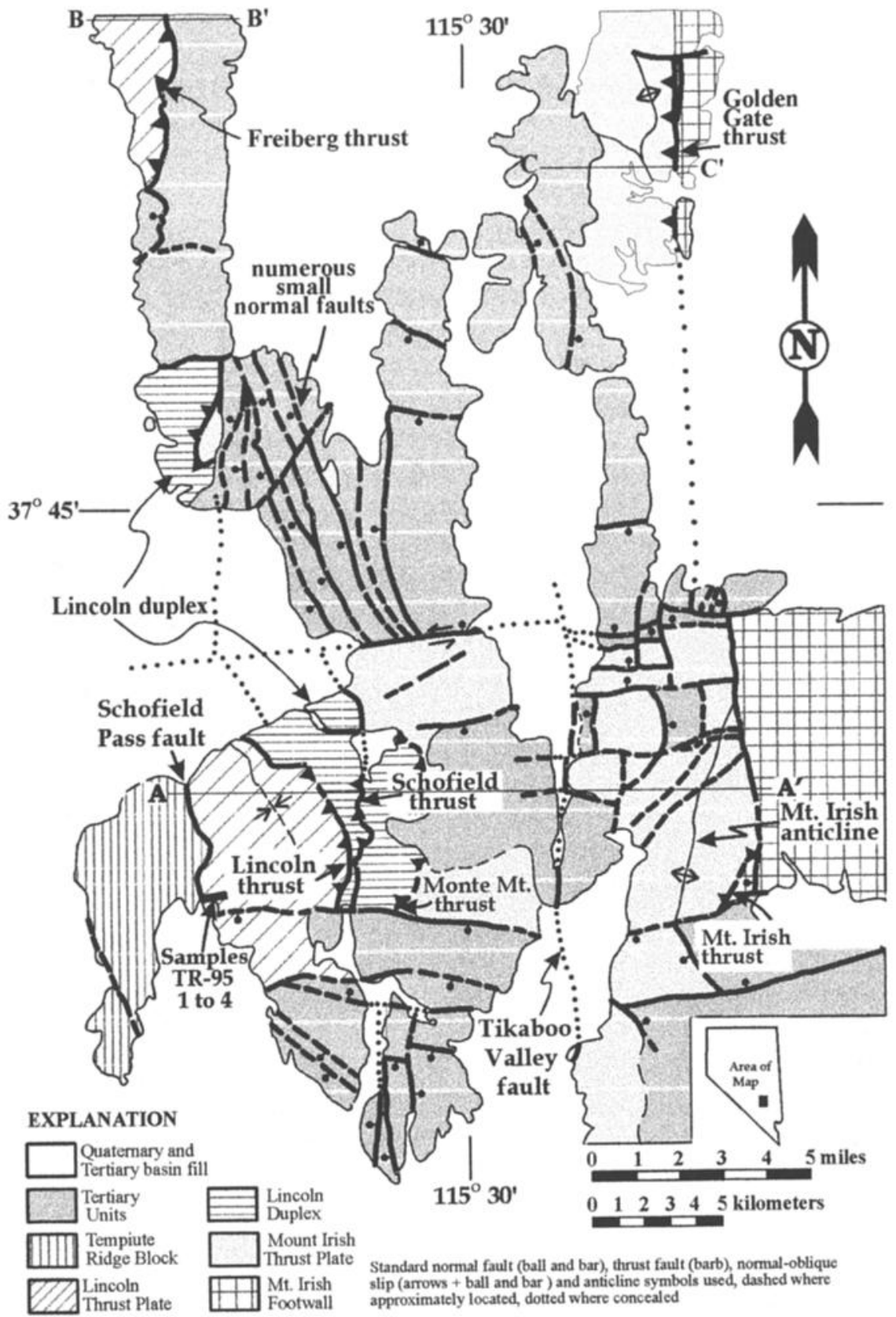

Figure 2. Tectonic map showing major structures of part of the Garden Valley thrust system and traces of major Cenozoic normal and strike-slip faults that overprint them.

structurally to the west through successive thrust plates, as might be expected crossing an east vergent thrust belt. The angular discordance across the unconformity mainly reflects folding and tilting of Paleozoic rocks during thrusting and only locally within one thrust plate includes the effects of pre-Oligocene extension which was of small magnitude.

Late Oligocene age tuffs unconformably overlie Devonian and Mississippian rocks in the Golden Gate-Mount Irish thrust plate, which is the easternmost thrust plate (Figures 1 and 2). Restoration of cross sections to thrust belt geometry must account for the moderate $\left(20^{\circ}-35^{\circ}\right)$ westward dip of compaction foliation in these ash flow tuffs. Tertiary normal faults commonly displace these tuffs in the Mount Irish Range and are rare in the southern Golden Gate Range. Also, in this thrust plate, one prevolcanic normal fault crops out in the eastern Timpahute Range.

Tertiary tuffs exposed at the southern end of the Worthington Mountains unconformably overlie Mississippian rocks that lie in a duplex above this thrust plate. The unconformity is low to moderate angle, dips gently east, and is cut and tilted by west dipping Cenozoic normal faults.

In the central and eastern parts of the Timpahute Range, shallow to moderately west dipping Tertiary ash flow tuffs overlie 
Rimrock - Freiberg - Lincoln Thrust Plate

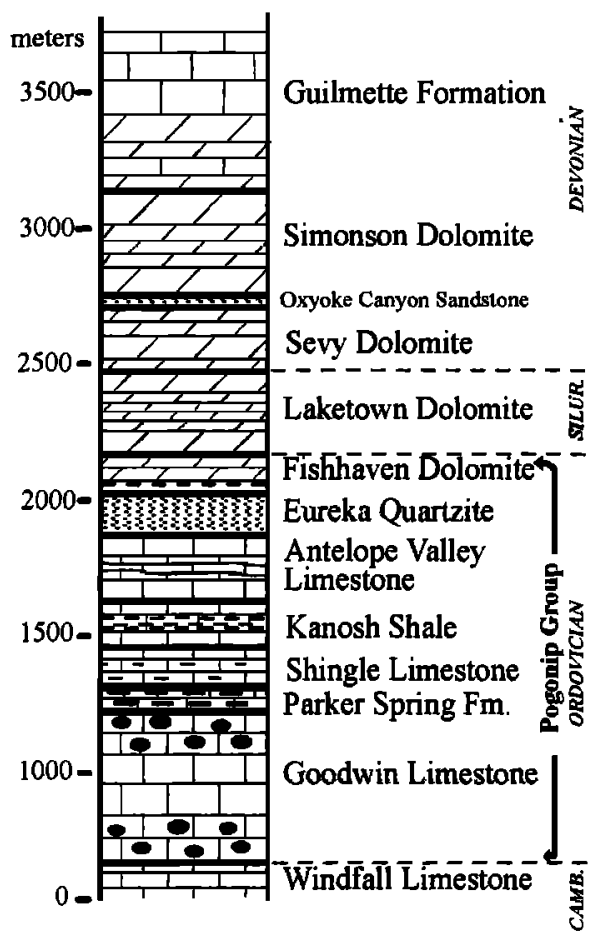

Mt. Irish - Golden Gate Thrust Plate

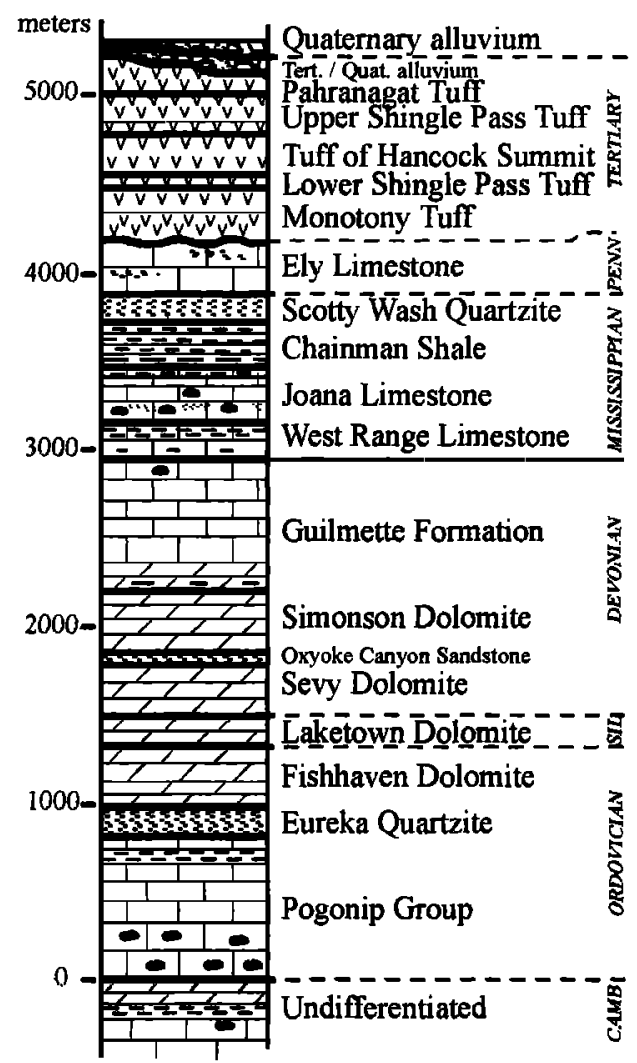

Figure 3. Representative stratigraphy of the Garden Valley thrust system. Differences in the Ordovician units are important for distinguishing the thrust plates. Stratigraphy of the Rimrock-Freiberg-Lincoln thrust plate is modified from Bartley and Gleason [1990]. The Mount Irish-Golden Gate thrust plate column also includes the unconformably overlying Cenozoic units, which were deposited after thrusting. The standard lithologic symbols are used. Dark ovals indicate chert nodules.

Ordovician to Devonian rocks in the Lincoln plate, which structurally overlies the duplex and the underlying Mount Irish thrust plate. The sub-Tertiary unconformity is not preserved on the northern continuation of this thrust plate in the Worthington Mountains, which causes greater uncertainty in reconstructing the preextensional geometry of this area.

Tertiary volcanic and sedimentary rocks overlie Ordovician to Devonian strata of the Rimrock thrust plate and Ordovician strata of the Sawmill plate in the Grant and Quinn Canyon Ranges. PreOligocene removal of mid-Paleozoic strata appears to be a distinctive feature of the Sawmill thrust plate as a result of its high structural position.

Relationships across the sub-Tertiary unconformity on the Schofield Canyon thrust plate, including the Timber Mountain anticline, are uncertain. Field exposures are insufficient to determine if Oligocene tuffs exposed in the Troy Canyon area [Cebull, 1967, 1970; Fryxell, 1988] depositionally overlie Cambrian strata of the overturned limb of the Timber Mountain anticline or if they were faulted into that position.

\section{Age of Contraction}

The age of contraction on the Garden Valley thrust system is only widely bracketed by stratified rocks. Thrusts in the system cut or fold strata as young as Pennsylvanian. No known Permian or Mesozoic strata crop out in the area. The oldest strata not involved in shortening are Oligocene strata, which overlie the Golden Gate, Mount Irish, and Lincoln thrusts or thrust plates. However, farther north in the central Nevada thrust belt, Permian and Cretaceous rocks are deformed [e.g., Taylor et al., 1993; Vandervoort and Schmitt, 1990].

Four small plutons cut structures or tilted strata in the Garden Valley thrust system. These plutons were suggested previously to be Cretaceous or Cretaceous to Tertiary in age, so improved geochronology could constrain the timing of thrusting. The plutons either have not been dated previously or were dated only by either the $\mathrm{K} / \mathrm{Ar}$ or $\mathrm{Rb} / \mathrm{Sr}$ method. We therefore conducted $\mathrm{U} / \mathrm{Pb}$ geochronology in an effort to bracket more narrowly the age of thrusting. The new data indicate plutons of both Tertiary and Cretaceous ages.

The Willow Creek stock cuts west vergent structures in the upper plate of the Sawmill thrust in the Quinn Canyon Range [Bartley and Gleason, 1990]. Six zircon fractions were analyzed from a sample of this stock (Table 1 and Figure 5). The zircons have low $U$ and radiogenic $\mathrm{Pb}$ concentrations. For that reason, a K-feldspar separate was analyzed to determine the isotopic composition of common $\mathrm{Pb}$ and the correction to the zircon data (Table 1). The analyses define 

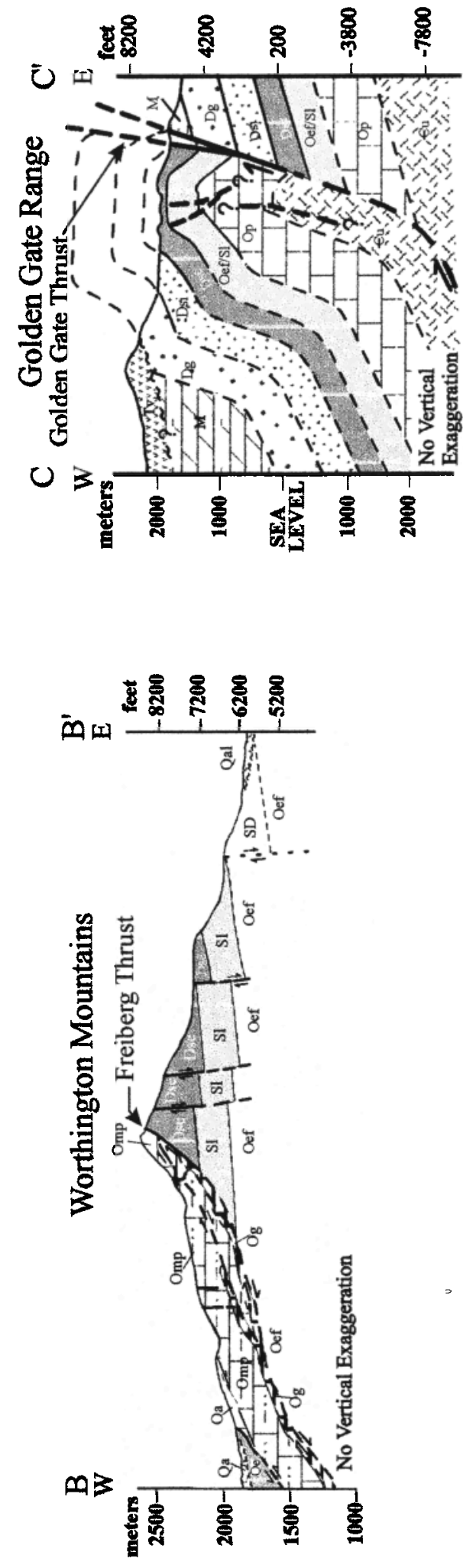

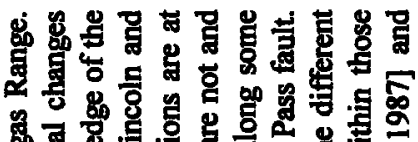

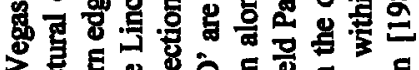
窟

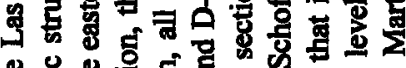

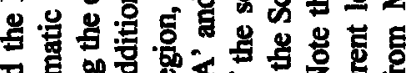

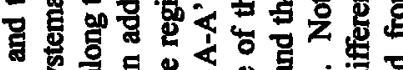

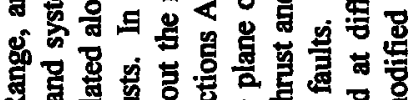

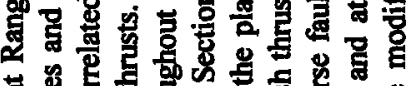

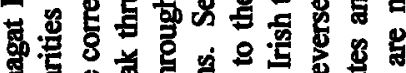

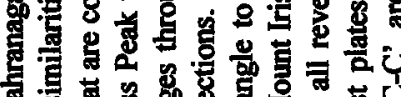

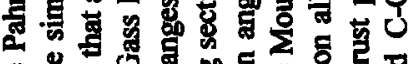

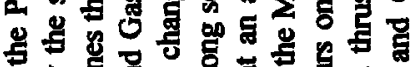

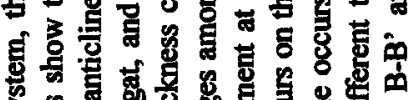

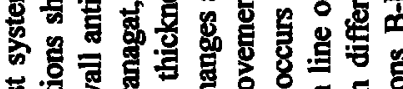
5

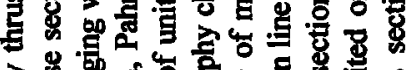

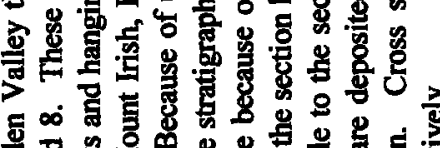

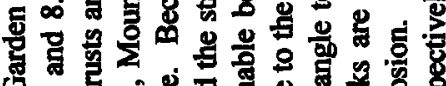
N

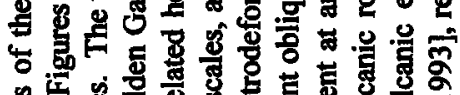

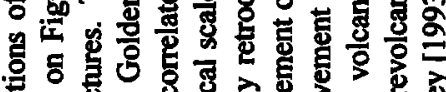

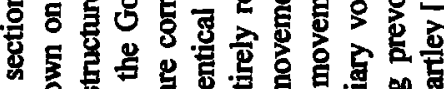

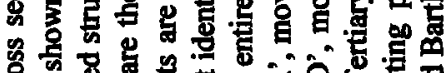

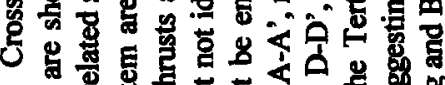

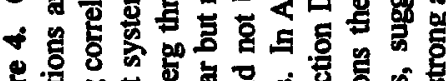

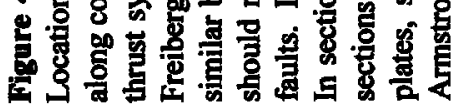




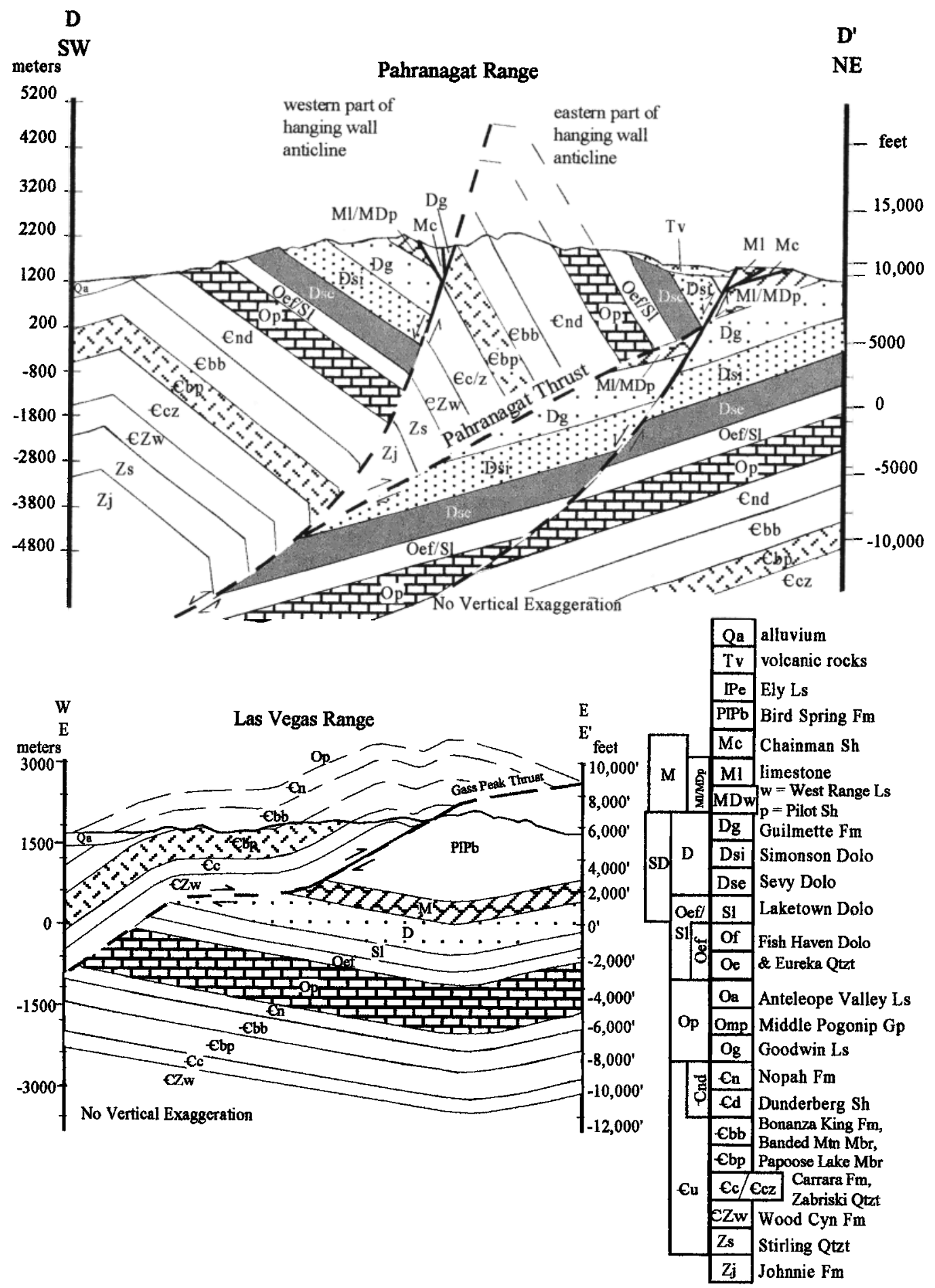

Figure 4. (continued)

a discord with a lower intercept of $31.9 \pm 2.3 \mathrm{Ma}$ that is interpreted as the age of magmatic crystallization. The Quinn Canyon Range includes part of a major Cenozoic volcanic center [e.g., Sargent and Houser, 1970], and this date is within error of $\mathrm{Ar} / \mathrm{Ar}$ ages from Tertiary volcanic strata near there [e.g., Taylor et al., 1989; Best et al., 1993]. We therefore interpret the Willow Creek stock to be an Oligocene subvolcanic intrusion. The upper intercept age is 1381 $\pm 27 \mathrm{Ma}$, interpreted as the $\mathrm{U} / \mathrm{Pb}$ age of xenocrystic zircon. This age is somewhat younger than typical basement ages for this region, but xenocrystic zircon could have been derived from Neoproterozoic clastic strata believed to underlie the area.

Contact metamorphism associated with emplacement of the Freiberg stock, a granite stock near the northern end of the Worthington Mountains, overprints structures related to the Freiberg thrust [Martin, 1987]. Three analyzed zircon fractions define a discordant linear array on a concordia plot with a lower intercept age 


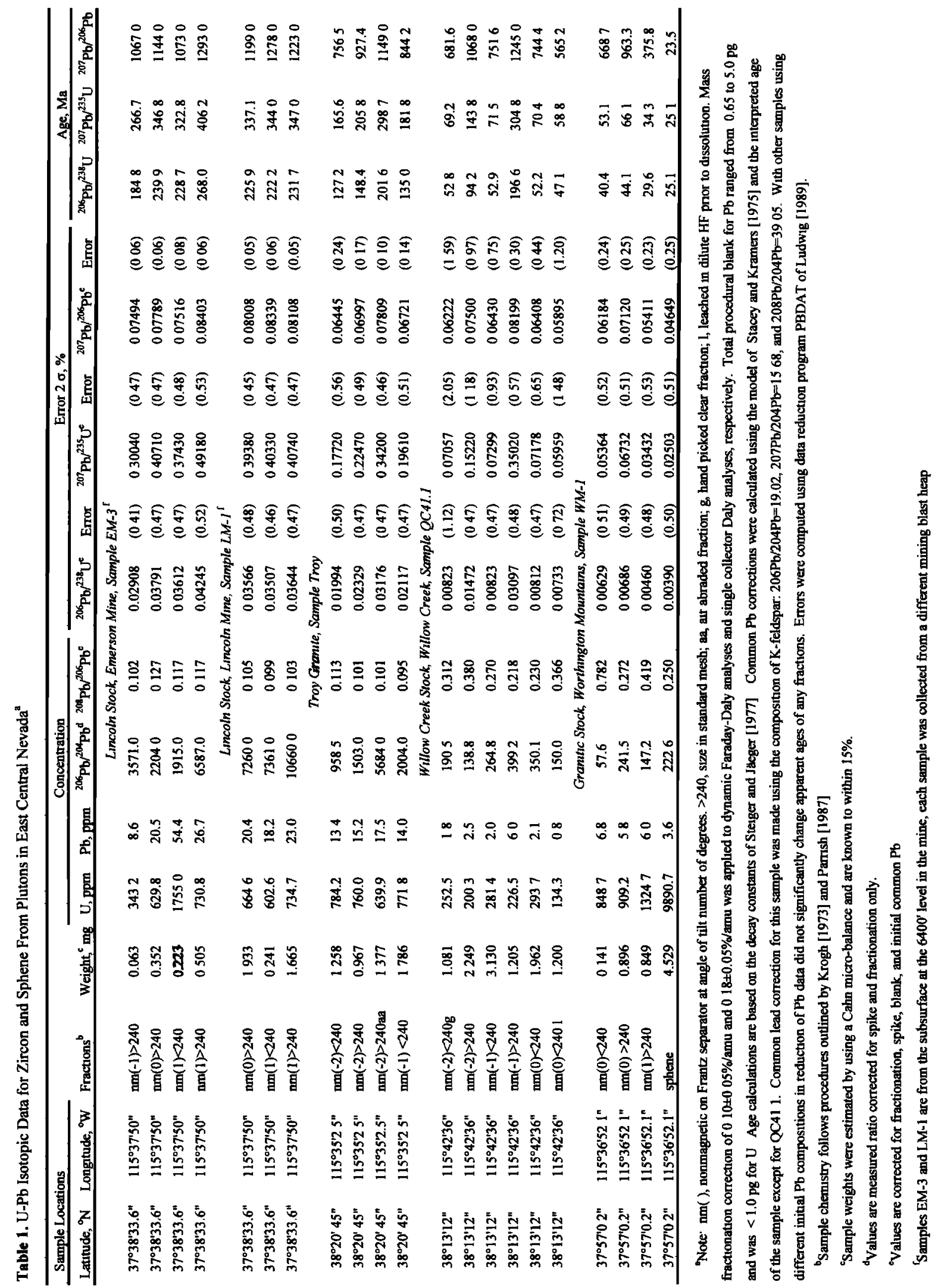



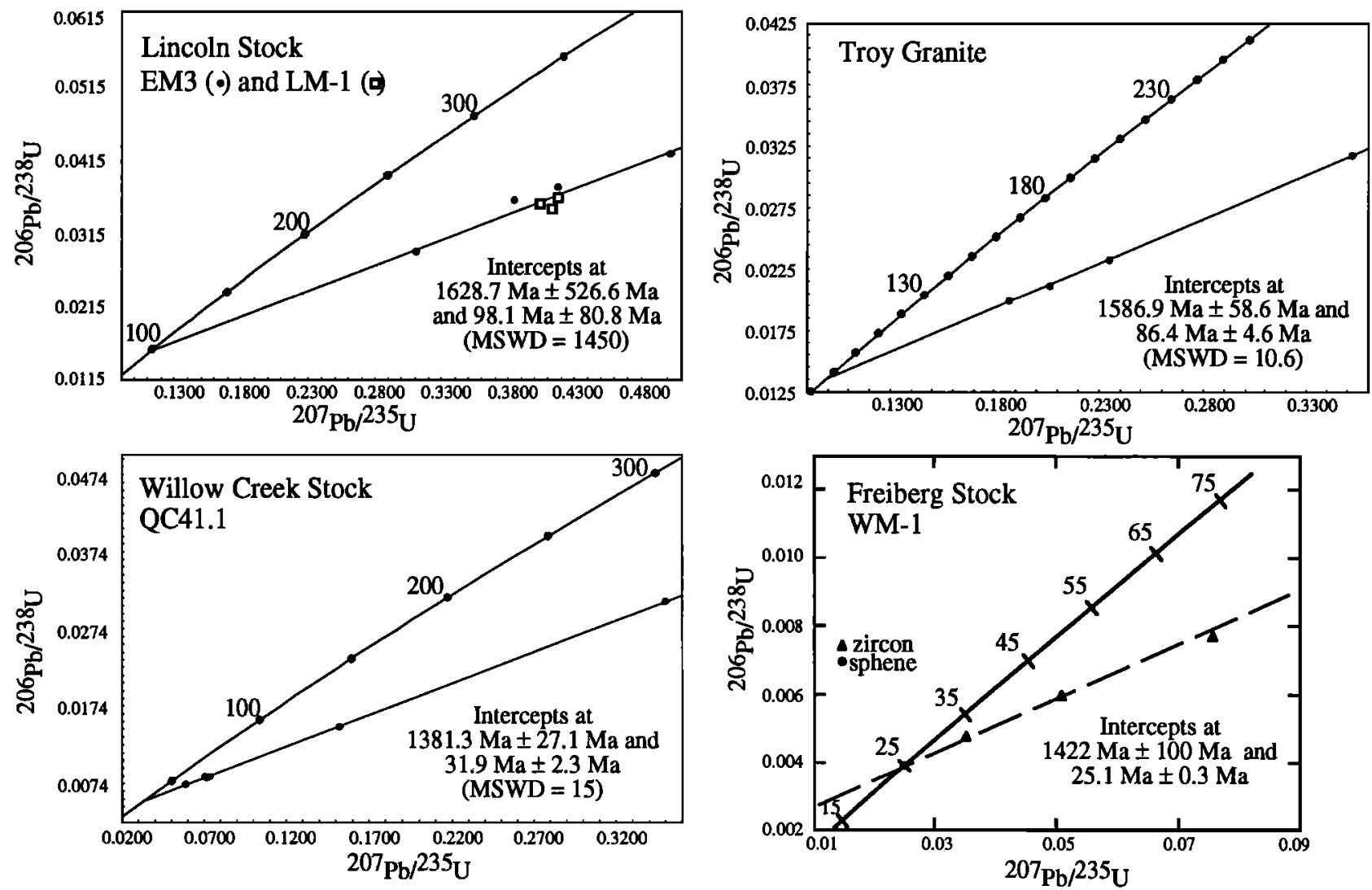

Figure 5. U/Pb concordia diagrams plotted from analyses of samples of plutons that cut structures in the Garden Valley thrust system. These plutons were suggested previously to be Cretaceous or Cretaceous-Tertiary in age, and thus $\mathrm{U} / \mathrm{Pb}$ dating was done to better define the age of contraction or to determine whether the plutons would better constrain the age of contraction. Pluton locations are shown in Figure 1. Zircon fractions were analyzed from all stocks. In addition, sphene was analyzed from the Freiberg stock. For the Lincoln stock the circles and squares indicate analyses that came from two different samples from the same part of the stock. Note that the scales vary among the diagrams.

of $24.9 \pm 3.4 \mathrm{Ma}$ and an upper intercept of $1490 \pm 480 \mathrm{Ma}$ (Figure 5). A single sphene fraction yielded a concordant age of $25.1 \mathrm{Ma}$. The sphene and zircon data when regressed together yield lower and upper intercept ages of $25.1 \pm 0.3 \mathrm{Ma}$ and $1420 \pm 100 \mathrm{Ma}$, respectively (Figure 5). The lower intercept and concordant sphene ages overlap within uncertainties, and the pattern of zircon discordance is characteristic of inherited xenocrystic zircon. Therefore, the lower intercept age defined by joint regression of the zircon and sphene data is interpreted as the age of crystallization of the Freiberg stock. The age and location of the Freiberg stock are consistent with it also being a subvolcanic intrusion related to the Tertiary volcanic center exposed in the adjacent Quinn Canyon Range [e.g., Martin and Bartley, 1989]. The upper intercept age is considered to reflect an inherited component with an age that is statistically indistinguishable from that of the Willow Creek stock, which is consistent with the intrusions sharing a common source.

More restrictive age limits are placed on contractional structures by the Lincoln and Troy stocks. Paleozoic strata on Tempiute Ridge were steeply tilted, presumably by east vergent folding related to the Lincoln or a structurally higher thrust before the Lincoln stock was intruded (Appendix 1). K-Ar dates on biotite from the stock of 90.0 $\pm 2.7,95.0 \pm 2.9$, and 97.9 \pm 3.0 Ma (Krueger and Schilling [1971] recalculated with constants of Steiger and Jäeger [1977]) suggest that the stock cooled through $\sim 250^{\circ}-300^{\circ} \mathrm{C}$ at $\sim 90-98 \mathrm{Ma}$. The relatively narrow contact aureole and lack of regional metamorphism suggest that the Lincoln stock was emplaced at a shallow crustal level. Therefore the $\mathrm{K}-\mathrm{Ar}$ ages may record cooling soon after emplacement of the pluton and may be close to the crystallization age of the pluton. Two samples (EM-3 and LM-1) from different parts of the same phase of the Lincoln stock (Table 1) were analyzed to determine a $\mathrm{U} / \mathrm{Pb}$ age. In all, seven zircon fractions were analyzed (Table 1 and Figure 5). The data yield a poorly defined lower intercept age of $98 \pm 81 \mathrm{Ma}$. The scatter in the data is not significantly reduced when data from only one sample are plotted (Figure 5). The origin of the scatter is uncertain, but given the ubiquitous evidence for xenocrystic zircon inherited from a Proterozoic source, it is likely to reflect overprinting of $\mathrm{Pb}$ loss on discordance due to inherited zircon. Heterogeneity of the original xenocrystic zircon populations also is possible. However, the lower intercept age is consistent with the K/Ar ages from the stock, and we therefore favor the interpretation that the pluton is mid-Cretaceous in age. 
In the central Grant Range, the Troy stock cross cuts the overturned limb of the Timber Mountain anticline, a large east vergent fold interpreted to have formed at a relatively deep structural level within the central Nevada thrust stack (Figure 1) [Fryxell, 1988]. The Troy stock data yield a four-point array that defines a lower intercept of $86.4 \pm 4.6 \mathrm{Ma}$ (Figure 5), which is interpreted as the crystallization age of the stock. The upper intercept is $1587 \pm 59$ $\mathrm{Ma}$, consistent with regional basement ages.

On the basis of these limited data we propose that much, perhaps all, thrusting in the central Nevada thrust belt was complete by early Late Cretaceous time. Regionally, contraction in the central Nevada thrust belt is bracketed between the Permian and Cretaceous by cross-cutting relations [e.g., Armstrong, 1968; Taylor et al., 1993]. The intrusions discussed above provide the Late Cretaceous upper age limit of deformation. Several ranges in the northern central Nevada thrust belt expose carbonate-dominated Lower to Middle Permian platformal strata, some of which are folded and thrusted. These strata include Pennsylvanian-Permian Ely Limestone (as defined by Lawson [1906] and Steele [1960]), Permian Arcturus Formation, Permian Carbon Ridge Formation, and Permian Riepe Spring Formation [e.g., Taylor, 1990; Taylor et al., 1993; Overtoom, 1994]. Late Permian tectonism in the area cannot be excluded based on possible Permian synorogenic conglomerate in the northern Pancake Range [Perry, 1991, 1992] and Permian conglomerate of uncertain tectonic significance in the Eureka area to the north [e.g., Gallegos and Wardlaw, 1992].

\section{Garden Valley Thrust System}

The Garden Valley thrust system originally included the Sawmill, Rimrock, Freiberg, and Golden Gate thrusts. Observations reported here allow us to correlate the Lincoln and Mount Irish thrusts in the Timpahute-Mount Irish area to thrusts in the Garden Valley thrust system and the Mount Irish thrust southward to the Pahranagat and Gass Peak thrusts. These correlations form a key step toward regional correlation and regional tectonic interpretation of the thrust system. In the following sections we describe briefly the thrust belt structures exposed in the Quinn Canyon and Grant Ranges, Worthington Mountains, Timpahute and Golden Gate Ranges, and Mount Irish, proceeding generally from north and west to south and east across the belt. This direction also is generally from structurally highest to structurally lowest through the thrust stack with the exception of the Schofield Canyon thrust.

\subsection{Sawmill Thrust}

The Sawmill thrust is the structurally highest known thrust of the Garden Valley system, and is exposed in structural windows in Sawmill and Hooper canyons in the Quinn Canyon Range (Figure 1). Oligocene volcanic rocks unconformably overlie upper plate Ordovician strata at both windows. Bartley and Gleason [1990] described the thrusts and interpreted their modification by Cenozoic normal faults. They concluded that the lower plate of the Sawmill thrust is the Rimrock thrust plate. In the Sawmill Canyon window [Murray, 1985] the thrust places Cambrian and Ordovician limestone upon Devonian dolostone. The Sawmill Canyon window provides a strike-parallel exposure of the thrust and yields little information about fault geometry or vergence. In the Hooper Canyon window the Sawmill thrust cuts up section to the southeast through both footwall Silurian and Devonian dolostones and upper plate Upper Cambrian strata. West vergent minor thrusts and folds contained within the upper plate 3-4 km to the west of the window (Willow Creek backthrust zone) expose Neoproterozoic-Lower Cambrian Prospect Mountain Quartzite. This relation indicates the absence of a significant decollement at any stratigraphic level from Lower Cambrian to Lower Devonian. Cross-section analysis indicates at least $5 \mathrm{~km}$ of thrust slip at the exposed ramp, but a larger value cannot be excluded [Bartley and Gleason, 1990]. The thinner and more basinal facies of Cambro-Ordovician rocks in the Sawmill thrust plate relative to other thrust plates in the area is consistent with but does not require large displacement across the Sawmill thrust.

\subsection{Schofield Canyon Thrust and the Timber Mountain Anticline}

The Schofield Canyon thrust and Timber Mountain anticline crop out in the southem Grant Range (Figure 1). The thrust ramps southward from Ordovician Goodwin Limestone to Ordovician Eureka Quartzite in the footwall and through the Cambrian Little Meadows and Windfall formations in its hanging wall. The throw of the thrust is estimated to be $2.7 \mathrm{~km}$ [Fryxell, 1991]. The recumbent Timber Mountain anticline, located in the hanging wall of the thrust, is interpreted to be genetically related to it. The Timber Mountain anticline is intruded discordantly by the Troy Granite $(86.5+/-4.6 \mathrm{Ma})$ which formed a relatively narrow contact metamorphic aureole that overprints and thus postdates both anticline-related structures and regional metamorphic mineral assemblages.

The Schofield Canyon thrust and Timber Mountain anticline are located in the footwall of a large Cenozoic low-angle normal fault, the Troy Peak fault [Fryxell, 1988], whereas other mapped thrust belt structures in the Grant and Quinn Canyon ranges lie in its hanging wall. Uncertainties in the direction and magnitude of slip across the Troy Peak fault make structural correlations across it speculative. Because it is the only exposed thrust that involves metamorphic rocks, the Schofield Canyon thrust may be either a structurally lower thrust or a deeper exposure of one of the other thrusts.

Cole and Cashman [1999] suggest that this deepest thrust may correlate to the Belted Range thrust exposed in the Nevada Test Site region. The structural complexity in the Grant Range makes correlation difficult; however, the Schofield Canyon thrust has less stratigraphic separation than the Belted Range thrust (2.7 compared to $7 \mathrm{~km}$ ) and may be structurally lower.

\subsection{Rimrock, Freiberg, and Lincoln Thrusts and Related Structures}

5.3.1. Rimrock thrust. The Rimrock thrust [Bartley and Gleason, 1990] crops out on the east side of the southem Grant Range (Figure 2) and perhaps locally on the west side. The thrust was first mapped by Cebull [1970] and Sainsbury and Kleinhampl [1969] who did not distinguish among the primary thrust contact and two major Tertiary normal faults that excise the thrust plane: the Troy Peak fault [Frixell, 1988, 1991; Taylor et al., 1993] and the Wadsworth Ranch fault [Bartley and Gleason, 1990]). The Tertiary faults obscure the geometry and kinematics of the thrust. In the southem Grant Range the thrust dips gently to the northwest and places Ordovician Pogonip Group limestone on Devonian dolostone with a stratigraphic throw of $\sim 1.2 \mathrm{~km}$. It cuts down section northward along strike in both its footwall and hanging wall to place Ordovician Goodwin Limestone over Silurian Laketown Dolomite. 
Across strike the thrust cuts up section to the southeast in both its hanging wall and footwall, indicating southeast vergence.

5.3.2. Freiberg thrust. The north striking Freiberg thrust is the main contractional structure exposed in the Worthington Mountains [Tschanz and Pampeyan, 1970; Martin, 1987]. The Freiberg thrust ramps up section to the east at a moderate angle $\left(30^{\circ}-50^{\circ}\right)$ through both hanging wall and footwall strata. The thrust cuts gradually upsection to the south in its hanging wall, progressively placing Ordovician Pogonip Group limestone and Eureka Quartzite upon a footwall of Devonian dolostone. Stratigraphic throws range from 0.6 to $1.2 \mathrm{~km}$ (Figure 4). Mesoscale folds above the thrust verge eastward. Along its southernmost exposure a complex array of upper plate splays and breakback thrusts above the basal Freiberg thrust plane suggests a complex and perhaps prolonged history of slip [Martin, 1987].

5.3.3. Lincoln thrust. The Lincoln thrust [Tschanz and Pampeyan, 1970] crops out in the western Timpahute Range (Figures 1 and 3) and places Ordovician Pogonip Group or Eureka Quartzite over the Lincoln duplex. Cambrian rocks are exposed in stratigraphic continuity with Ordovician rocks that are cut by the thrust, which requires that the thrust cuts up section to the east in the hanging wall. Rocks within the Lincoln thrust plate define an upright open syncline. The axial surface strikes north-northwest and dips steeply west. A small thrust emerging from the core of the syncline structurally disrupts the axial surface. The thrust presently strikes $\mathrm{N} 20^{\circ}-25^{\circ} \mathrm{E}$, dips $37^{\circ}-45^{\circ} \mathrm{W}$, and ramps across both footwall and hanging wall strata. Removal of $20^{\circ}-25^{\circ} \mathrm{E}$ of eastward Cenozoic tilt indicates a postcontraction thrust dip of $57^{\circ}-70^{\circ} \mathrm{W}$.

5.3.4. Lincoln duplex. The Lincoln duplex (named here) is well exposed in the Timpahute Range and the southern Worthington Mountains. We interpret the duplex to end northward at a location south of exposures of the Freiberg thrust because of the relatively strong correlation of the Lincoln and Freiberg thrusts, as presented in Section 6. A large stratigraphic separation, east striking highangle fault that separates the duplex from the main part of the Worthington Mountains appears to be the northern terminus of the duplex.

In the Timpahute Range the duplex is floored by the Schofield or Monte Mountain thrusts and roofed by the Lincoln thrust (Figures 2 and 4). Although these thrusts were recognized and named by Tschanz and Pampeyan [1970] and Chamberlain and Chamberlain [1990], our mapping differs from theirs. The duplex contains rocks as old as the Ordovician Pogonip Group and as young as the Mississippian Chainman Shale (Figure 3) that are deformed by north striking, gently to moderately west dipping thrust faults, north trending folds, and east striking faults that may be tear faults. The Schofield thrust places Ordovician rocks (Eureka Quartzite in the south and Pogonip Group in the north) upon Mississippian (Chainman Shale and Joana Limestone). The footwall immediately below the Schofield thrust is folded into an overturned syncline. The Monte Mountain thrust crops out east of the Schofield thrust in the eastern Timpahute Range and dies out northward. At its maximum exposed stratigraphic separation the Monte Mountain thrust places sandstone and carbonate of the lower Devonian Guilmette Formation over Mississippian limestone. Relations of the Monte Mountain thrust to the Mount Irish anticline and thrust are obscured by north striking normal faults of both prevolcanic and late Cenozoic ages and a Cenozoic anticline-syncline pair (Figure 4). The small stratigraphic separation and decrease of slip northward across the thrust within the range both suggest that the Monte Mountain thrust is not regionally continuous.
The Lincoln duplex in the Worthington Mountains comprises rocks ranging from the Devonian Guilmette Formation to the Mississippian Chainman Shale that are folded and imbricated by several gently west dipping faults. Folds measured in Mississippian limestone plunge gently north (Figure 6), suggesting a maximum shortening direction that trends roughly $\mathrm{N} 80^{\circ} \mathrm{E}$. Low-angle faults variously place younger rocks on older and older on younger. However, rocks within the duplex are overturned locally, and therefore younger-over-older relations across faults may reflect either thrusting in an overturned section or overprinting by lowangle normal faults.

Our correlation of imbricated rocks in the southern Worthington Mountains with the Lincoln Duplex is not unique because in the southern Worthington Mountains the roof thrust, if present, has been eroded away. The imbricate zone in the Worthington Mountains therefore may have lacked a roof thrust and may have been an imbricate fan. However, the low-angle faults in the southern Worthington Mountains converge eastward, suggesting that the thrusts merged updip to form a duplex rather than separately intersecting the surface as an imbricate fan.

\subsection{Tempiute Ridge Block and the Schofield Pass Fault}

5.4.1. Tempiute Ridge block. North trending Tempiute Ridge forms the western Timpahute Range and contains homoclinal Pennsylvanian to Ordovician beds dipping $30^{\circ}-60^{\circ} \mathrm{E}$ (Figure 2). These Paleozoic strata are cut by the Cretaceous Lincoln stock. The homocline is bounded on the east by the Schofield Pass fault and on the west by the west dipping normal fault that defines the range front.

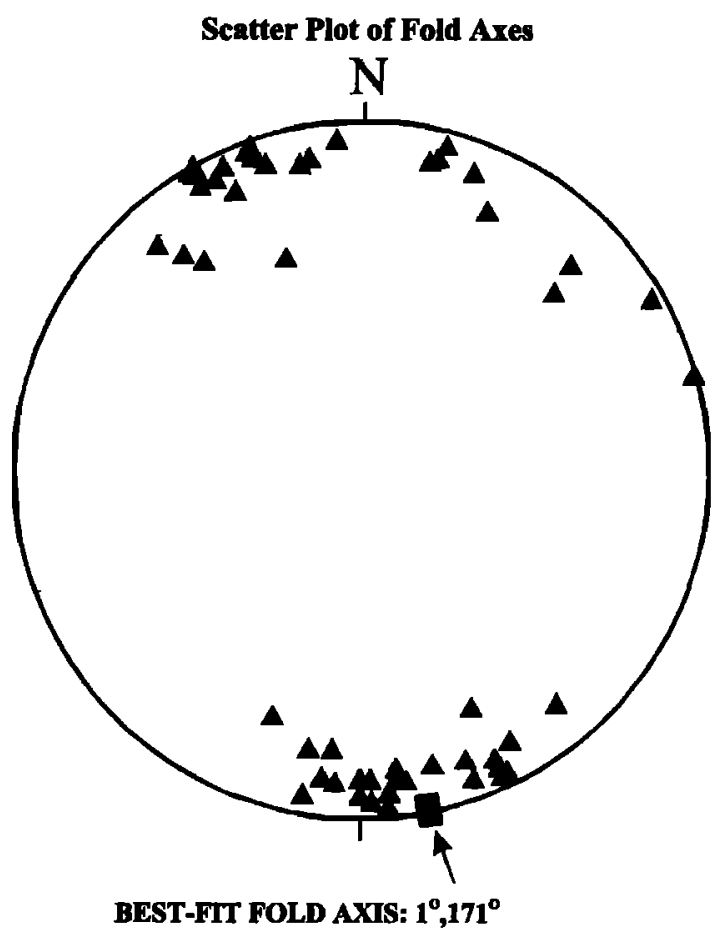

Figure 6. Lower-hemisphere equal-area plot showing the attitudes of fold axes measured in Mississippian limestone within the Lincoln duplex in the southern Worthington Mountains. The overall trend of the fold axes suggests roughly east-west shortening within the duplex. 

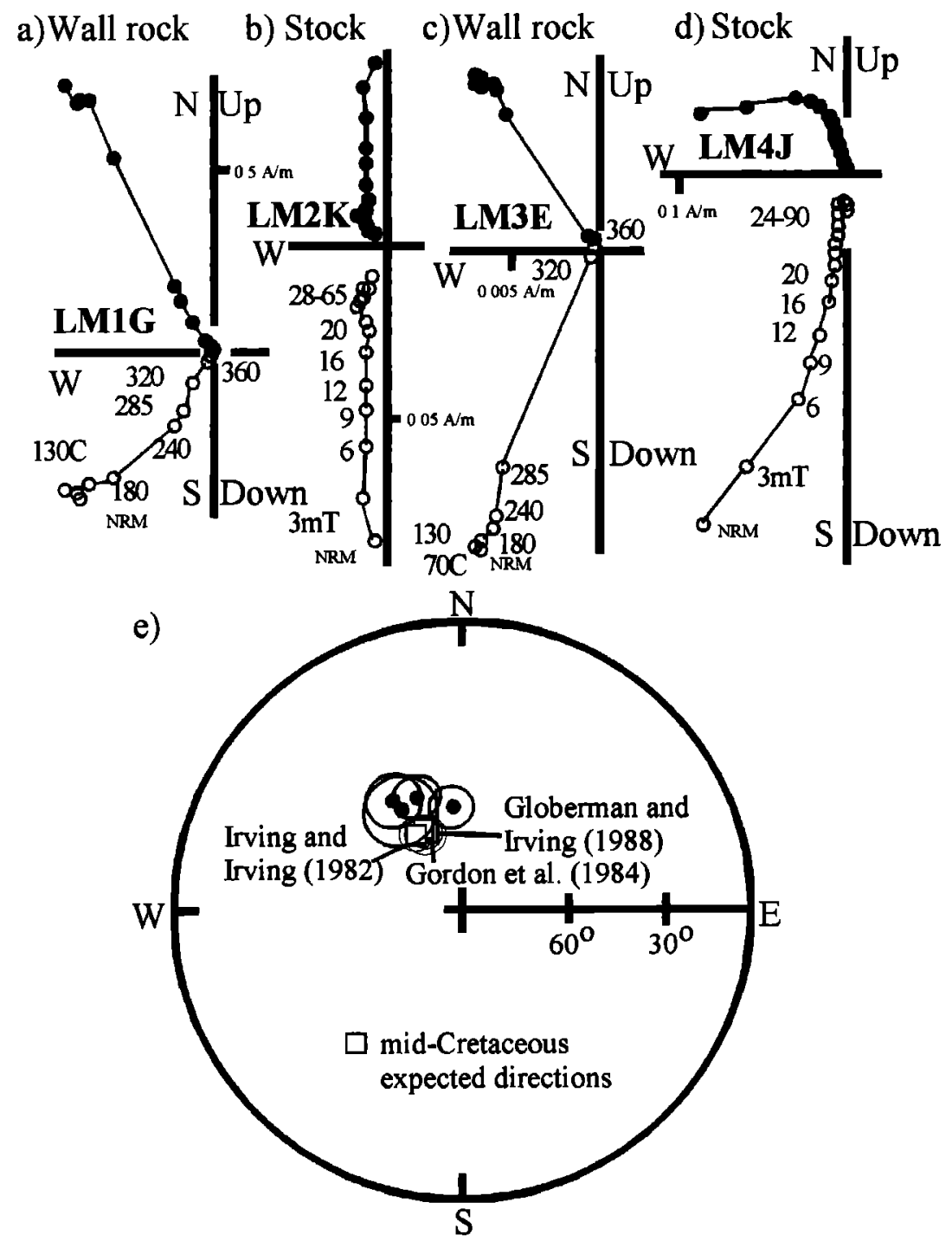

Figure 7. Paleomagnetic results from the Lincoln stock and carbonate wall rocks. (a-d) Zijderveld-type orthogonal plots illustrating sample responses to progressive demagnetization, where the endpoint of the magnetization vector measured after each demagnetization step is projected onto the horizontal (solid circles) and vertical (open circles) planes. Demagnetization treatments are indicated along the vertical projections. Samples LM1G and LM3E are carbonate wall rock samples that we interpret to have been remagnetized by intrusion of the Lincoln stock. LM2K and LM4J are samples from the Lincoln stock; most samples from the intrusion are heavily contaminated by a strong viscous remanance carried in low-coercivity phases that made it difficult to isolate a stable primary remanance. (e) Lower-hemisphere equal-area projection of site mean directions for the four sites (circles) and midCretaceous expected directions (squares) derived from three compilations of North America paleomagnetic poles, both with associated projected cones of $95 \%$ confidence.

Paleomagnetic data (Appendix 1) from the Lincoln stock and carbonate wall rocks indicate no more than $15^{\circ}$ of southeast side down tilting of the stock and its wall rocks since intrusion (Figure 7). This implies that wall rock bedding was steeply tilted prior to intrusion. Because the Schofield Pass fault truncates the contact aureole of the stock and therefore was active after intrusion, we conclude that the majority of tilting of the Tempiute Ridge block is significantly older than and unrelated to displacement across the Schofield Pass fault.
5.4.2. Schofield Pass fault. The Schofield Pass fault, located in the western Timpahute Range, places rocks as young as Pennsylvanian in the Tempiute Ridge block on the west against strata as old as Cambrian (Table 2) on the east, a stratigraphic separation of $\sim 4000 \mathrm{~m}$ (Figure 3). The straight trace of the Schofield Pass fault across topography indicates a steep dip, but poor exposure prevents determination of the dip direction. The Schofield Pass fault cuts the contact metamorphic aureole of the Cretaceous Lincoln stock that intrudes the northern Tempiute Ridge 
Table 2. Fossils From Cambrian Rocks in the Timpahute Range ${ }^{\mathrm{a}}$

\begin{tabular}{|c|c|c|c|c|}
\hline $\begin{array}{l}\text { Meters Below } \\
\text { Ordovician } \\
\text { Goodwin Lime }\end{array}$ & Sample & $\begin{array}{l}\text { Fossil } \\
\text { Type }\end{array}$ & Fossil(s) & Zone \\
\hline 37 & TR-95-4 & $\begin{array}{l}\text { inarticulate } \\
\text { brachipods }\end{array}$ & Lannarssonella sp & Elvinia \\
\hline 55 & TR-95-3 & trilobites & Kindbladia sp & Elvmia \\
\hline 100 & TR-95-2 & trilobites & $\begin{array}{l}\text { Dunderbergia } \\
\quad \text { varıagranula Palmer }\end{array}$ & Dunderbergia \\
\hline 100 & TR-95-2 & trilobites & $\begin{array}{l}\text { Pterocephalia } \\
\text { compare concava Palmer }\end{array}$ & Dunderbergia \\
\hline 100 & TR-95-2 & trilobites & $\begin{array}{l}\text { Homagnostus tumidosus } \\
\text { (Hall and Whitfield). }\end{array}$ & Dunderbergia \\
\hline 113 & TR-95-1 & trilobites & Meteoraspis sp. & Crepicephalus \\
\hline 113 & TR-95-1 & tralobites & Llanoaspis sp. & Crepicephalus \\
\hline 113 & TR-95-1 & tolobites & Kingstonia sp. & Crepicephalus \\
\hline
\end{tabular}

${ }^{a}$ Fossils collected from a section through the lowest stratigraphic unit in the Lincoln thrust plate, just east of the Schofield Pass fault, indicate the unit age (Figure 2). The biostratigraphic zones range from uppermost Middle Cambrian (Crepicephalus) to Middle Upper Cambrian (Ehvinia) [Paimer, 1998]. They show that (1) the Lincoln thrust must cut down into the Cambrian and (2) the Schofield Pass fault cuts Cambrian racks on its east side. Fossils were collected under the direction of M. N Rees and were identified by A. R. Palmer (personal communication, 1998)

homocline. Several east striking Cenozoic normal faults that probably postdate early slip on the Schofield Pass fault transfer slip onto it, reactivating it as a strike-slip fault (Figure 4). We therefore infer at least some post mid-Cretaceous and postintrusion slip across the fault.

5.4.3. Structural position of the Tempiute Ridge block. The structural position of the Tempiute Ridge block in the thrust stack and the type and structural significance of the Schofield Pass fault are uncertain. Roeder [1989] interpreted the Schofield Pass fault to be the Lincoln thrust, synformally folded such that it reintersects the Earth's surface to the west of its frontal exposure, and therefore interpreted the Tempiute Ridge block to be a window into the underlying Mount Irish thrust plate. However, on the basis of geometric evidence and reasoning presented below, we interpret the Schofield Pass fault to be a west side down normal or oblique-slip fault along which the Tempiute Ridge block was emplaced from a structurally higher position.

Rocks of the Tempiute Ridge block range up to Pennsylvanian in age, yet the youngest rocks in the footwalls of both the Mount lrish and Lincoln thrusts are Mississippian. This relationship requires that either the thrust system cuts down section in the direction of transport or the Tempiute Ridge block is part of the Lincoln or a higher thrust plate. Because thrust faults normally cut up section in the direction of transport [e.g., Dahlstrom, 1969], and because no evidence contradicts this assumption in the Garden Valley thrust system, Taylor et al. [1994] inferred a thrust beneath Tempiute Ridge which they suggested was structurally higher than the Lincoln thrust. However, the geometries of strata in the Tempiute Ridge block and the Lincoln thrust plate also permit derivation of the Tempiute block from the Lincoln plate (Figure 4).

Pre Late Cretaceous tilting of the Tempiute Ridge block probably occurred during displacement across either the Lincoln or a higher thrust, whereas west side down movement across the Schofield Pass fault occurred significantly later. Field and regional relations are consistent with the Schofield Pass fault being a west dipping
Cenozoic high-angle normal fault that was reactivated as a strikeslip fault. However, we cannot exclude the possibility that the Schofield Pass fault was once a steeply east dipping reverse fault.

\subsection{Golden Gate, Mount Irish, and Pahranagat Thrusts}

5.5.1. Golden Gate thrust. The Golden Gate thrust is exposed for $-6.5 \mathrm{~km}$ on the eastern flank of the Golden Gate Range where it strikes generally north and dips $41^{\circ}-56^{\circ} \mathrm{W}$ after removing $24^{\circ}$ of westward Cenozoic tilt (Armstrong and Bartley [1993], on which the following summary is based). The thrust slip goes to zero where it terminates northward in a complex pattern of open folds and highangle faults. Net slip increases southward to $\sim 2.5 \mathrm{~km}$ such that the thrust places Ordovician rocks upon Mississippian Joana Limestone in the southernmost part of the range. The thrust defines a steep footwall ramp through gently dipping, weakly deformed strata of the footwall block. The main hanging wall structure is a gently north plunging, upright to steeply inclined anticline that opens northward into a boxfold. The western limb and subhorizontal top of the box fold project westward under Tertiary cover, leaving much of the back limb of the Golden Gate anticline unexposed. Imbricate splays along the thrust bound-horses that contain subvertical bedding.

5.5.2. Mount Irish Thrust. Although the Mount Irish thrust either has been excised by or reactivated as a Cenozoic fault along rnuch of its exposed length (Figure 2) [Bartley and Taylor, 1992], its geometry and footwall relations resemble those of the southem part of the Golden Gate thrust. The younger fault diverges southward from the thrust, leaving the Mount Irish thrust relatively unmodified on the south side of the range. At this location the thrust places uppermost Cambrian or lowermost Ordovician limestone upon a faulted and folded footwall of Mississippian and Devonian rocks (Figure 2). The fault presently dips $39^{\circ} \mathrm{W}$ in the south where the fault is unmodified. Removal of $20^{\circ}-25^{\circ}$ of westward Cenozoic tilting suggests that the thrust originally dipped $\sim 20^{\circ} \mathrm{W}$ at the end of thrust movement. Splays along the thrust-bound horses contain 


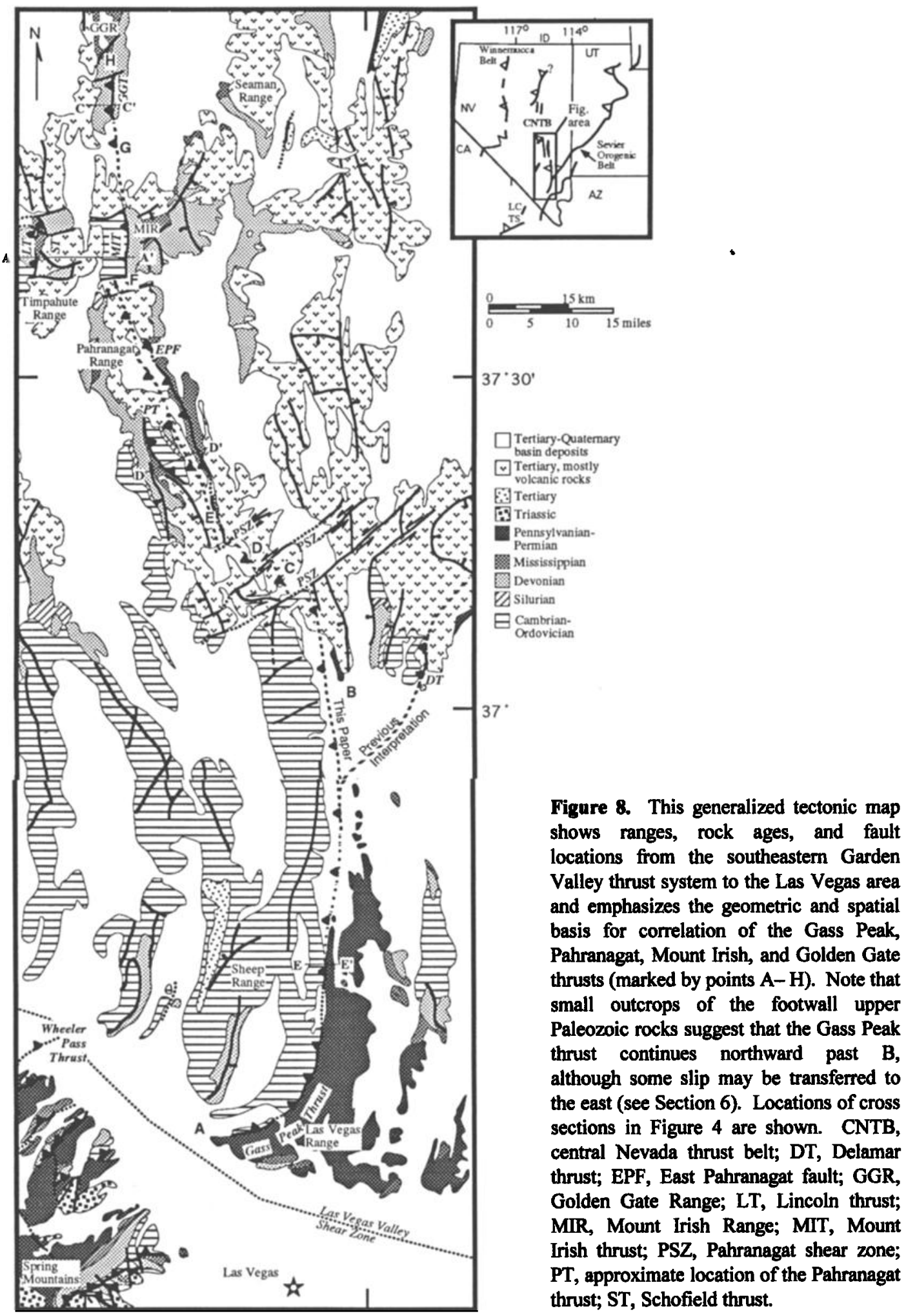


steeply dipping to overturned Devonian and Mississippian beds. The steep dip and the moderate- to high-angle truncation of footwall bedding both indicate that the exposed part of the thrust is a footwall ramp.

The upper plate structure is dominated by a large anticline here named the Mount Irish anticline (Figure 2). The fold is broadhinged and open, with a steeply dipping axial surface and a short eastern limb that ends at the thrust. Northward truncation of the Mount Irish anticline against the Mount Irish thrust where it is strongly modified by Cenozoic faulting suggests that the younger fault cut out at least parts of the thrust rather than reactivated it. Removal of $20^{\circ}-25^{\circ}$ of Cenozoic-age westward tilt suggests that the bedding on the eastern limb generally was nearly horizontal or dipped gently east (except immediately near the thrust) and bedding on the western limb dipped moderately to steeply west just after contraction.

The geometry and structural development of the Mount Irish thrust and anticline resemble relations exposed in the Golden Gate Range to the north and the Pahranagat Range to the south. Implications of this resemblance are examined in Section 6.

5.5.3. Pahranagat thrust. The Pahranagat thrust is cut out or reactivated by a Cenozoic normal fault or covered by Cenozoic strata throughout the Pahranagat Range (Figures 1 and 4). Several lines of evidence indicate the existence of this thrust. (1) A fault on the eastern side of the range offsets Tertiary volcanic rocks in a normal sense but places older Paleozoic rocks (Devonian) over younger (Mississippian). This relationship would result if a Cenozoic normal fault cut out or reactivated a preexisting thrust fault (the Pahranagat thrust) if the normal fault had less slip than the thrust fault. However, a similar relationship might result if a postvolcanic rock normal fault cut through and displaced an east dipping Mesozoic or early Tertiary normal fault that moved before emplacement of Oligocene strata in the Pahranagat Range [Taylor et al., 1989; Taylor and Bartley, 1992; Axen et al., 1993]. (2) Reverse faults, including the East Pahranagat thrust (Figures 1 and 8), and an associated syncline crop out east of the fault just described [Tschanz and Pampeyan, 1970; Jayko, 1990]. These reverse faults and the syncline resemble faults that cut a syncline east of the Golden Gate and Mount Irish thrusts. However, this syncline is better preserved than in areas to the north. (3) The three large panels of Paleozoic rocks in the Pahranagat Range have different dips, implying the presence of a hanging wall anticline similar to that in the hanging walls of the Golden Gate and Mount Irish thrusts (Figure 4d). In the western panel, strata of the Cambrian Bonanza King Formation through Mississippian limestone are exposed dipping $30^{\circ}-50^{\circ} \mathrm{ENE}$. These rocks form the western part of the anticline. A west dipping nonplanar normal fault (Badger Mountain fault of Jayko, 1990) separates the western and central panels, and tilted the western panel $\sim 30^{\circ}-50^{\circ} \mathrm{ENE}$. In the central panel, strata of the Cambrian Bonanza King Formation through Mississippian limestone are exposed dipping $70^{\circ}-30^{\circ} \mathrm{NE}$. The central panel forms the eastern part of the anticline. The eastern panel, interpreted to be the footwall of the Pahranagat thrust, exposes Devonian and Mississippian strata that dip $20^{\circ}-30^{\circ}$ WSW. As constructed in Figure 4, the Pahranagat thrust places Upper Cambrian rocks over Devonian Guilmette Formation, a stratigraphic separation that is slightly larger than that on the southern end of the Mount Irish thrust. In addition, the Pahranagat thrust has a hanging wall anticline, a footwall ramp, and footwall splays or imbricate faults.

\section{Discussion}

\subsection{Structural Correlations}

6.1.1. Golden Gate-Mount Irish-Pahranagat-Gass Peak thrust. Tschanz and Pampeyan [1970] and Armstrong [1991] correlated the Golden Gate thrust with the Mount Irish thrust. We concur with this interpretation for several reasons. First, the structural styles and geometries of the thrusts are similar. Each has a broad-hinged hanging wall anticline with the eastern limb imbricated by backward breaking thrust splays to form horses of steeply dipping east facing strata. Second, the Mississippian limestone section above the thrusts includes a thin-bedded facies that is uncommon elsewhere. Finally, correlating the two thrusts results in a systematic increase in stratigraphic separation passing southward from the exposed thrust tip in the Golden Gate Range.

We correlate the Golden Gate-Mount Irish thrust southward with the Pahranagat thrust, which also has a broad-hinged hanging wall anticline above footwall and hanging wall ramps and complex imbrication along the thrust plane. However, the bedding in footwall horses along the Pahranagat thrust, in part defined by the East Pahranagat fault, dips more gently than in horses along the Golden Gate-Mount Irish thrust. Upper Paleozoic strata on the east side of the East Pahranagat fault are deformed into an asymmetric to overturned, east vergent syncline, which we correlate with footwall synclines in similar age strata beneath the Mount Irish and Gass Peak thrusts. The Paleozoic strata that define this fold can be traced northward in nearly continuous outcrop to within a few kilometers of footwall strata of the Mount Irish thrust. In contrast, no specific structural context for this fold is provided by previous interpretations [e.g., Jayko, 1990]. This thrust correlation continues the systematic increase in stratigraphic separation to the south along the thrusts.

Finally, we correlate the Mount Irish-Golden Gate-Pahranagat thrust southward with the Gass Peak thrust in the Las Vegas Range (Figure 8) [Longwell et al., 1965; Burchfiel, 1965; Guth, 1980, 1981]. The Gass Peak thrust is a major thrust of the Sevier orogenic belt in southem Nevada and may accommodate the largest slip of any Sevier belt thrust at that latitude [Guth, 1981, 1990; Wernicke et al., 1984]. The Mount Irish, Golden Gate, Pahranagat, and Gass Peak thrusts all lie nearly along strike of each other in a region that under-went only small-magnitude Cenozoic extension. The tip line of this regional thrust system lies near point $\mathrm{H}$ in the Golden Gate Range (Figure 8). Passing southward, stratigraphic separation increases to Ordovician over Devonian (point G), Cambrian over Mississippian and Devonian (F), Lower Cambrian on Pennsylvanian (B), and, finally, Neoproterozoic on Pennsylvanian (A). Three small left steps occur near $37^{\circ} \mathrm{N}$ latitude between points $\mathrm{E}$ and $\mathrm{B}$ (Figure 8). The steps reflect Cenozoic movement across strands of the dominantly left-lateral Pahranagat shear zone. Between points $B$ and A the Gass Peak thrust surface is concealed by alluvium on the west side of the Las Vegas Range, but its location and northward strike are well defined by exposures of upper and lower plate strata as far north as the trace of the late Neogene to Quatemary Pahranagat shear zone near $37^{\circ} \mathrm{N}$ latitude (Figure 8). Our suggested thrust correlation places Cambrian and younger Paleozoic rocks that crop out west of the East Pahranagat fault in the Pahranagat Range in the Gass Peak thrust plate.

The common alternative interpretation of the trace of the Gass Peak thrust [e.g., Armstrong, 1968] is that it tums east near $37^{\circ} \mathrm{N}$ latitude and continues into Utah (Figure 8). The Delamar thrust fault lies in the general area of this eastward deflection [cf. Tschanz 
and Pampeyan, 1970; Page, 1992]. We suggest that correlation of the Gass Peak and Delamar thrusts is inappropriate for three reasons. (1) In outcrops nearest the Gass Peak thrust, Devonian rocks lie in the footwall of the Delamar thrust. If the Gass Peak and Delamar thrusts correlate, then the thrust would have to cut down section from Pennsylvanian to Devonian in the footwall in a direction subparallel to the transport direction. (2) The Pahranagat shear zone accommodated left-normal oblique slip [Tschanz and Pampeyan, 1970; Ekren et al., 1977; Jayko, 1990]. Therefore the trace of the Gass Peak thrust should be offset to the southwest not to the northeast, passing northward across the Pahranagat shear zone. (3) The Delamar thrust fault places rocks as old as Cambrian in a hanging wall syncline rather than an anticline over Devonian to Pennsylvanian footwall rocks. Although we cannot exclude the possibility of an along-strike change in fault-fold relations, we regard the consistency of fault-fold patterns provided by our correlation as more likely. However, our suggested correlation permits the possibility that some slip related to the Gass Peak or Pahranagat thrusts was transferred to the east, particularly along the basal decollement of the thrust system. Indeed, the relatively rapid northward termination of the thrust in the Golden Gate Range probably suggests that slip was relayed to more frontal thrusts in Utah.

In summary, present data favor continuation of the Gass Peak thrust along its northward strike to link with the Pahranagat, Mount Irish, and Golden Gate thrusts to a lateral tip in the Golden Gate Range. No direct field evidence favors the conventional interpretation that the Gass Peak thrust turns northeastward into Utah, although some slip transfer in this direction is likely. This proposed thrust correlation implies a direct structural tie between the Garden Valley thrust system and the Gass Peak-Wheeler Pass thrust [e.g., Armstrong, 1968; Burchfiel et al., 1992] of the Sevier thrust belt.

6.1.2. Lincoln-Freiberg-Rimrock thrusts. Bartley and Gleason [1990] correlated the Rimrock thrust southward with the Freiberg thrust. This correlation was based on along-strike locations within the same Tertiary normal-fault block, similar stratigraphic separations, and a similar facies of the middle Pogonip Group in the hanging wall. We retain the correlation and, for similar reasons, correlate the Freiberg thrust with the Lincoln thrust. In particular, Pogonip Group facies in the Timpahute Range resemble those in the Worthington Mountains and the southern Grant Range but differ from those in the Mount Irish-Golden Gate thrust plate and the Quinn Canyon Range above the Sawmill thrust.

The continuation of the Rimrock-Freiberg-Lincoln thrust farther to the south is less clear. Possible correlative structures include thrusts exposed on the Nevada Test Site and the Pintwater anticline [cf. Barnes and Poole, 1968; Cole and Cashman, 1999]. The Pintwater anticline is a regional-scale anticline above the Gass Peak thrust that is inferred to be the major pre-Tertiary structure in the Sheep, Desert, Pintwater, and Spotted Ranges of southern Nevada. The anticline was disrupted by the late Tertiary Sheep Range detachment system [Wernicke et al., 1984; Guth et al., 1988; Guth, 1990], and its reconstructed pre-Tertiary geometry is uncertain. Guth [1990] suggested that the Pintwater anticline is a fault-bend fold formed above a footwall ramp of the Gass Peak thrust. Caskey and Schweickert [1992] interpreted it to be cored by a blind antiformal duplex to which the Gass Peak was the floor thrust. If so, the blind duplex represents imbrication on a scale an order of magnitude larger than the Lincoln duplex. Although the Lincoln thrust and duplex may link to a blind duplex under the Pintwater anticline, no observations specifically favor this interpretation.
Alternatively, the Lincoln thrust may correlate southward with the Spotted Range thrust, which places Middle Cambrian strata on Mississippian rocks (Figure 1) [Cole and Cashman, 1999], a stratigraphic separation similar to but slightly larger than that of the Lincoln thrust at its southern exposures. Footwall rocks of the Spotted Range thrust contain tight to isoclinal, southeast vergent folds [Barnes et al., 1982] that are not observed below the Lincoln thrust. The Spotted Range thrust also does not lie precisely along strike of the Lincoln thrust, but Cenozoic extension in the vicinity of the Spotted Range probably is greater than in the Timpahute Range and could account for the difference [cf. Guth, 1990].

\subsection{Timing of Deformation in the Cordilleran Fold and Thrust Belt}

Correlation of the Golden Gate-Mount Irish thrust with the Gass Peak thrust implies that the Garden Valley thrust system overlaps in age with the Sevier thrust belt. Age brackets on deformation in the Garden Valley thrust system (Pennsylvanian to mid-Cretaceous; ca. $85 \mathrm{Ma}$ ) are sufficiently wide to be easily compatible with such a correlation. In this case it is worthwhile to examine implications for the time-space pattern of deformation.

The timing of Sevier thrusts in southern Nevada and southeastem California is largely based on ages of prekinematic and synkinematic intrusions and on the age of the synorogenic Lavinia Wash conglomeratic sequence [Burchfiel and Davis, 1971, 1988; Carr, 1980, 1983; Cowan and Bruhn, 1992; Burchfiel et al., 1992]. This evidence indicates that contraction across the southern Sevier thrust belt occurred between $\sim 200$ and $92 \mathrm{Ma}$, i.e., Middle Jurassic to early Late Cretaceous time [Burchfiel and Davis, 1975; Walker et al., 1995].

The age of initiation Sevier thrusting is controversial. However, all data are consistent with activity between latest Jurassic and Eocene times. DeCelles et al. [1995] used clast provenance to tie foreland basin conglomerate deposits to specific thrust sheets and, on that basis, interpreted thrusting in the Sevier belt to range from Early Cretaceous to Paleocene. On the basis of the geometry, contact relations, facies patterns, and provenance of foredeep deposits and overlap assemblages, Lawton et al. [1997] inferred that the emplacement of thrust sheets in south-central Utah began in the latest Jurassic and persisted into Eocene time. In contrast, Schwans and Campion [1997] used sequence stratigraphy of foreland basin strata and overlap assemblages to suggest that Sevier thrusting did not begin until the Albian (late Early Cretaceous).

Schwans and Campion [1997] therefore inferred that Sevier thrusting began in Utah very near the end of thrusting in southern Nevada. Combined with our revised thrust correlations, a logical conclusion would be that the southern Nevada thrust belt is not continuous with the type Sevier belt in Utah, but instead continues northward where it is represented by the central Nevada thrust belt. Such a reinterpretation would have dramatic implications for the time-space pattern of Mesozoic orogenesis in the western United States. However, we do not prefer this alternative because substantial evidence favors the older inception of thrusting in Utah proposed by Lawton et al. [1997].

We therefore interpret the Garden Valley thrust system and, more generally, the central Nevada thrust belt to represent an internal branch of the Sevier thrust belt. Continuation of the Mesozoic regional thrust system into central Nevada significantly impacts interpretation of foreland-hinterland relations in the Sevier orogenic belt as well as regional paleogeographic reconstructions [cf., Levy and Christie-Blick, 1989]. Armstrong [1968, 1982], followed by 
many others [e.g., Miller et al., 1983], interpreted east central Nevada and adjacent Utah to have undergone, at most, minor Mesozoic contraction and to lie in the hinterland of the Sevier thrust belt. This conclusion requires Paleozoic strata exposed in the Cenozoic metamorphic core complexes of the Sevier hinterland to have acquired their Mesozoic metamorphic mineral assemblages in the absence of significant tectonic burial [e.g., Armstrong, 1982; Miller et al., 1983]. However, central Nevada belt thrust sheets may contribute to tectonic burial. Recognition of the central Nevada thrust belt as a significant tectonic element linked to the Sevier thrust belt refutes Armstrong's [1968] interpretation of negligible crustal contraction in the hinterland of central and eastern Nevada. In addition, it suggests that the area typically called the hinterland of the Sevier thrust belt may have been the early formed part of the Cordilleran fold-and-thrust belt and only later lay in the hinterland, assuming generally normal-sequence thrusting.

\section{Conclusions}

We expand the definition of the Garden Valley thrust system such that it consists of the Sawmill, Schofield Canyon, the RimrockFreiberg-Lincoln, and Golden Gate-Mount Irish thrusts and the Lincoln duplex, exposed in the Grant, Quinn Canyon, Golden Gate, Timpahute, and Mount Irish Ranges and the Worthington Mountains. We propose that this thrust system is directly structurally linked to the Sevier orogenic belt by the correlation of the Golden Gate-Mount Irish thrust to the Gass Peak thrust of the Sevier belt in southern Nevada. The correlation implies that the Gass Peak thrust either does not continue northeastward or that only some of its slip is transferred or partitioned onto thrusts exposed in Utah. A direct link of the central Nevada thrust belt to the Sevier belt carries two further regional tectonic implications. First, it provides robust evidence of significant Sevier age crustal contraction in eastern Nevada, including the metamorphic core complex belt. Second, it suggests that eastern Nevada should be regarded not as an undeformed part of the hinterland of the Sevier orogenic belt but instead is an integral part of that fold-thrust belt.

\section{Appendix 1: Paleomagnetic Data and Methods}

To determine the timing of tilting relative to intrusion of Paleozoic strata exposed in Tempiute Ridge, we obtained paleomagnetic data from the mid-Cretaceous Lincoln stock (two sites) and carbonate wall rocks (two sites) within $25 \mathrm{~m}$ of the contact (Figure 2). Samples were collected as standard $2.5 \mathrm{~cm}$ cores using a portable drill. Specimen preparation, measurement of natural remanent magnetization, progressive demagnetization, and evaluation of the components of magnetization all follow standard procedures described elsewhere [e.g., Holm et al., 1993].

The overall response to progressive demagnetization of samples from the stock and contact rocks varied (Figure 7). The magnetization in contact-metamorphosed carbonate rocks is carried principally by pyrrhotite; this interpretation is based on the demagnetization behavior of these rocks. Pyrrhotite is reputed to be the dominant remanence carrier in contact-metamorphosed carbonate rocks [e.g., Gillett et al., 1982]. Alternating field (AF) demagnetization was ineffective in isolating a stable magnetization, yet thermal demagnetization resulted in essentially complete unblocking of the magnetization by $\sim 330^{\circ} \mathrm{C}$ (Figures $7 \mathrm{a}$ and $7 \mathrm{c}$ ). The principal remanent magnetic carrier in the Lincoln stock is magnetite of relatively low coercivity. About half of the samples from the stock yielded interpretable demagnetization results (Figures $7 \mathrm{~b}$ and $7 \mathrm{~d}$ ). The magnetization has a moderate positive inclination and a north to northwest declination (Figure 7e).

Samples from all four sites (two contact sites and two in the stock) yielded well-grouped magnetizations that were isolated over a range of moderate- to high-peak alternating fields or laboratory unblocking temperatures. Site mean directions from all sites are reasonably well defined (Figure $7 \mathrm{e}$ ) with an ags value of $<10^{\circ}$. The characteristic magnetizations are interpreted to reflect midCretaceous thermal remanence based on interpretation of published $\mathrm{K} / \mathrm{Ar}$ ages as the age of pluton emplacement. This is consistent with the normal field polarity obtained at all four sites. The four in situ site means are $7^{\circ}-10^{\circ}$ shallower in inclination but similar in declination to the mid-Cretaceous expected directions for the locality based on three estimates of mid-Cretaceous paleomagnetic poles (Figure 7) [Irving and Irving, 1982; Globerman and Irving. 1988; Gordon et al., 1984].

The lack of a declination anomaly between observed and expected directions suggests that the Tempiute Ridge block did not undergo significant vertical axis rotation since the mid-Cretaceous. This conclusion is consistent with paleomagnetic results from Oligocene ash flow tuffs in the Mount Irish area and the Golden Gate Range [Overtoom and Bartley, 1996; Overtoom, 1994].

Acknowledgments. This work was supported by American Chemical Society/Petroleum Research Fund grant 22462-AC2 to John M. Bartley; grants from Mobil Exploration and Producing, U.S., Inc., Chevron, and UNLV to Wanda J. Taylor; grants from Marathon Oil Company to Mark W. Martin, Joan E. Fryxell, and Phillip A. Armstrong; and grants from Sigma Xi, the Geological Society of America, the American Association of Petroleum Geologists, Mobil Exploration and Producing, and University of Utah to Phillip A. Armstrong. We appreciate the valuable reviews provided by Peter Guth and Hugh Hurlow. Special thanks to Jay Schofield for assisting with access into the area of the Lincoln/Emerson Mine in the Timpahute Range and to Bonnie Schofield for helping us keep in contact with the outside world during the field seasons. The stereonet program written by $R$. Allmendinger was used to plot structural data.

\section{References}

Allmendinger, R.W., Fold and thrust tectonics of the western United State exclusive of the accreted terranes, in The Cordilleran Orogen: Conterminous U.S., Geology of North America, vol. G-3, edited by B.C. Burchfiel, P.W. Lipman, and M.L. Zoback, pp. 583-607, Geol. Soc. of Am., Boulder, Colo., 1992.

Allmendinger, R., and T.E. Jordan, Mesozoic structure of the Newfoundland Mountains, Utah: Horizontal shortening and subsequent extension in the hinterland of the Sevier Belt, Geol. Soc. Am. Bull., 95, 1280-1292, 1984.

Allmendinger, R.W., D. Figueroa, D. Snyder, J. Beer, C. Mpodozis, and B.L. Isacks, Foreland shortening and crustal balancing in the Andes at $30^{\circ} \mathrm{S}$ latitude, Tectonics, 9, 789-809, 1990.
Armstrong, P.A., Structural geology of the Golden Gate Range, Nevada, M.S. thesis, 162 pp., Univ. of Utah, Salt Lake City, 1991.

Armstrong, P.A., and J.M. Bartley, Displacement and deformation associated with a lateral thrust termination, southern Golden Gate Range, southern Nevada, U.S.A., J. Struct. Geol., 15, 721-735, 1993. 
Armstrong, R.L., Sevier orogenic belt in Nevada and Utah, Geol. Soc. Am. Bull., 79, 429-458, 1968.

Armstrong, R.L., Low-angle (denudation) faults, hinterland of the Sevier orogenic belt, eastern Nevada and western Utah, Geol. Soc. Am. Bull., 83, 1729-1754, 1972.

Armstrong, R.L., Cordilleran metamorphic core complexes from southern Arizona to southerm Canada, Annu. Rev Earth Planet. Sci., 10, 129-154, 1982.

Axen, G.J., W.J. Taylor, and J.M. Bartley, Spacetime patterns of the onset of extension and magmatism, southern Great Basin, Nevada, Utah, and California, Geol. Soc. Am. Bull, 105, 56-76, 1993.

Barnes, H., and F.G. Poole, Regional thrust-fault system in the Nevada Test Site and vicinity, in Nevada Test Site, edited by E.G. Eckel, Mem. Geol. Soc. Am., II0, 233-238, 1968.

Barnes, H., E.B. Ekren, C.L. Rodgers, and D.C Hedland, Geologic and tectonic maps of the Mercury quadrangle, Nye and Clark counties, Nevada, U.S. Geol. Surv. Misc. Invest. Map. I-1I97, 1982.

Bartley, J.M., and G.C. Gleason, Tertiary normal faults superimposed on Mesozoic thrusts, Quinn Canyon and Grant Ranges, Nye County, Nevada, in Basin and Range Extensional Tectonics Near the Latitude of Las Vegas, Nevada, edited by B.P. Wemicke, Mem. Geol. Soc. Am., 176, 195-212, 1990.

Bartley, J.M., and W.J. Taylor, Barrier network model for Basin and Range faulting, $A A P G$ Bull. 76, 416, 1992.

Best, M. G., and S.K. Grant, Stratigraphy of the volcanic Needles Range Group in southwestern Utah, U.S. Geol. Surv. Prof. Pap. 1433-A, 3-28, 1987.

Best, M.G., and E.H. Christiansen, Limited extension during peak Tertiary volcanism, Great Basin of Nevada and Utah, J. Geophys. Res., 96, 13,509-13,528, 1991.

Best, M.G., E.H. Christiansen, and H. Blank, Jr., Oligocene calc-alkaline rocks of the Indian Peak volcanic field, Nevada and Utah, Geol. Soc. Am. Bull., 101, 1076-1090, 1989.

Best, M.G., et al., Oligocene-Miocene caldera complexes, ash-flow sheets, and tectonism in the central and southeastern Great Basin, in Crustal Evolution of the Great Basin and Sierra Nevada, Cordilleran and Rocky Mtn. Sect. Field Trip Guidebook, edited by M.M. Lahren, J.H. Trexler Jr., and C. Spinosa, pp. 285-311, Geol. Soc. of Am., Boulder, Colo., 1993.

Bird, P., Kinematic history of the Laramide orogeny in latitudes $35^{\circ}-49^{\circ} \mathrm{N}$, westem United States, Tectonics, $17,780-801,1998$.

Boyer, S.E., and D. Elliott, Thrust systems, AAPG Bull , 66, 1196-1230,1982.

Burchfiel, B.C., Structural geology of the Specter Range quadrangle, Nevada, and its regional significance, Geol. Soc. Am. Bull., 76, 175$192,1965$.

Burchfiel, B.C., and G.A. Davis, Clark Mountain thrust complex, in The Cordillera of Southeastern California, Geologic Summary and Field Trip Guide, Riverside Mus. Contrib. I, pp. 1-28, University of Calif. at Riverside, 1971.

Burchfiel, B.C., and G.A. Davis, Nature and controls of Cordilleran orogenesis, westem
United States: Extensions of an earlier synthesis, $A m$. J. Sci., 275-A, 363-396, 1975.

Burchfiel, B.C., and G.A. Davis, Mesozoic thrust faults and Cenozoic low-angle normal faults, eastem Spring Mountains, Nevada and Clark Mountains Thrust Complex, California, in This Extended Land, Geological Journeys in the Southern Basin and Range, Cordilleran Section Field Trip Guidebook, edited by D.L. Weide and M.L. Faber, pp. 87-106, Geol. Soc of Am., Boulder, Colo., 1988.

Burchfiel, B.C., G.S. Hamill, and D.E. Wilhelms, IV, Structural geology of the Montgomery Mountains and northem half of the Nopah and Resting Springs Ranges, Nevada and California, Geol. Soc. Am. Bull., 94, 1359-1376, 1983.

Burchfiel, B.C., D.S. Cowan, and G.A. Davis, Tectonic overview of the Cordilleran orogen in the western United States, in The Cordilleran Orogen: Conterminous U.S. Geology of North America, vol. G-3, edited by B.C. Burchfiel, P.W. Lipman, and M.L. Zoback, pp. 407-479, Geol. Soc. of Am. Boulder, Colo., 1992.

Carr, M.D., Upper Jurassic to Lower Cretaceous(?) synorogenic sedimentary rocks in the southem Spring Mountains, Nevada Geology, 8, 385-389, 1980.

Carr, M.D., Geometry and structural history of the Mesozoic thrust belt in the Goodsprings district, southern Spring Mountains, Nevada, Geol. Soc. Am. Bull., 94, 1185-1198, 1983.

Caskey, S.J., and R.A. Schweickert, Mesozoic deformation in the Nevada Test site and vicinity: Implications for the structural framework of the Cordilleran fold and thrust belt and Tertiary extension north of Las Vegas Valley, Tectonics, 11, 1314-1331, 1992.

Cebull, S.E., Bedrock geology of the southern Grant Range, Nye County, Nevada, Seattle, Washington, Ph.D. dissertation, 130 pp., Univ. of Washington, Seattle, 1967.

Cebull, S.E., Bedrock geology and orogenic succession in southern Grant Range, Nye County, Nevada, AAPG Bull., 54, 1828-1842, 1970.

Chamberlain, A.K., and R.L. Chamberlain, Monte Mountain thrust, additional confirmation of the Central Nevada thrust belt, Geol. Soc. Am Abstr. Programs, 22, 13, 1990.

Cole, J.C., and P.H. Cashman, Structural relationships of pre-Tertiary rocks in the Nevada Test Site region, southem Nevada, U.S. Geol. Surv. Prof. Pap., I607, 39 pp., 1999.

Cowan, D.S., and R.L. Bruhn, Late Jurassic to early Late Cretaceous geology of the U.S. Cordillera, in The Cordilleran Orogen: Conterminous U.S., Geology of North America, vol. G-3, edited by B.C. Burchfiel, P.W. Lipman, and M.L. Zoback, pp. 169-203, Geol. Soc. of Am., Boulder, Colo., 1992

Dahlstrom, C.D.A., Balanced cross sections, Can. J. Earth Sci., 6, 743-757, 1969.

Davis, D., J. Suppe, and F.A. Dahlen, Mechanics of fold-and-thrust belts and accretionary wedges, $J$. Geophys. Res., 88, 1153-1172, 1983.

DeCelles, P.G., T.F. Lawton, and G. Mitra Thrust timing, growth of structural culminations, and synorogenic sedimentation in the type Sevier orogenic belt, western United States, Geology, 23, 699-702. 1995.

Dobbs, S.W., J.A. Carpenter, and D.G. Carpenter,
Structural analysis from the Roberts Mountains to the Diamond Mountains, Nevada: Estimates on the magnitude of contraction and extension, in Structural and Stratigraphic Relationships of Devonian Reservoir Rocks, East-Central Nevada, 1993 Field Conference Guidebook, edited by C.W. Gillespie, pp. 5157, Nev. Petrol. Soc, Reno, 1993.

Ekren, E.B., P.P. Orkild, K.A. Sargent, and G.L. Dixon, Geologic map of Tertiary rocks, Lincoln County, Nevada, U.S. Geol. Surv. Misc. Field Studies Map, I-1041, 1977.

Fleck, R.J., Tectonic style, magnitude and age of deformation in the Sevier orogenic belt in southern Nevada and eastern California, Geol. Soc. Am. Bull., 81, 1705-1720, 1970.

Fryxell, J.E, Geologic map and descriptions of stratigraphy and structure of the west-central Grant Range, Nye County, Nevada, Geol. Soc. Am. Map Chart Ser, . MCH-064, 1988.

Fryxell, J.E, Tertiary tectonic denudation of an igneous and metamorphic complex, westcentral Grant Range, Nye County, Nevada, in Geology and Ore Depasits of the Great Basin: Symposium Proceedings, edited by G.L. Raines et al., pp. 87-92, Geol. Soc. of Nev. Reno, 1991.

Gallegos, D.M., and B.R. Wardlaw, Asselian (Early Permian) conodont fauna from the Garden Valley Formation, Sulphur Springs Range, Eureka County, Nevada, Geol. Soc. Am Abstr. Programs, 6, A13, 1992.

Gillett, S.L., V.C. Hover, and J.J. Papike, The Notch Peak contact metamorphic aureole, Utah: Paleomagnetism of the metasedimentary rocks and the quartz monzonite stock, $J$. Geophys. Res., 87, 5375-5390, 1982.

Globerman, B.R., and E. Irving, Mid-Cretaceous paleomagnetic reference field for North America: Restudy of $100 \mathrm{Ma}$ intrusive rocks from Arkansas, J. Geophys. Res., 93, 11,721$11,733,1988$

Gordon, R.A., A. Cox, and S. O'Hare, Paleomagnetic Euler poles and the apparent polar wander and absolute motion of North America since the Carboniferous, Tectonics, 3, 499, 1984.

Guth, P.L., Geology of the Sheep Range, Clark County, Nevada, Ph.D. dissertation, 189 pp. Mass. Inst. Technol., Cambridge, 1980.

Guth, P.L., Tertiary extension north of the Las Vegas Valley shear zone, Sheep and Desert Ranges, Clark County, Nevada, Geol. Soc. Am. Bull., 92, 763-771, 1981

Guth, P.L., Superposed Mesozoic and Cenozoic deformation, Indian Springs Quadrangle, southern Nevada, in Basin and Range Extensional Tectonics Near the Latitude of Las Vegas, Nevada, edited by B.P. Wemicke, Mem. Geol. Soc. Am., J76, 237-249, 1990.

Guth, P.L., D.L. Schmidt, J. Deibert, and J.C. Yount, Tertiary extensional basins of northwestem Clark County, in This Extended Land: Geological Journeys in the Southern Great Basin, Cordilleran Section Field Trip Guide, edited by D.L. Weide and M.L. Faber, pp. 239-253, Geol. Soc. of Am., Boulder, Colo., 1988.

Heller, P.L., S.S. Bowdler, H.P. Chambers, J.C. Coogan, E.S. Hagen, M.W. Shuster, N.S Winslow, and T.F. Lawton, Time of initial thrusting in the Sevier orogenic belt, IdahoWyoming and Utah, Geology, 14, 388-391, 1986. 
Holm, D.K., J.W. Geissman, and B. Wernicke, Tilt and rotation of the footwall of a major normal fault system: Paleomagnetism of the Black Mountains, Death Valley extended terrane, California, Geol. Soc. Am. Bull., 105. 1373-1387, 1993.

Hose, R.K., and M.C. Blake Jr., Geology and mineral resources of White Pine County, Nevada, Nev. Bur. Mines Geol. Bull., Part I, 85, 1A35, 1976.

Hurtubise, D.O., Stratigraphy and structure of the Seaman Range and Fox Mountain area, Lincoln and Nye Counties, Nevada, with emphasis on the Devonian system, Ph.D. Dissertation, 443 pp., Colo. School of Mines, Boulder, 1989.

Hurtubise, D.O., and E.A. du Bray, Stratigraphy and structure of the Seaman Range and Fox Mountain, Lincoln and Nye Counties, Nevada, U.S. Geol. Surv. Bull., 1988B, 31 pp.,1992.

Irving, E., and G.A. Irving, Apparent polar wander paths from Carboniferous through Cenozoic and the assembly of Gondwana, Geophys. Surv., 5, 141-188, 1982.

Jayko, A.S., Shallow crustal deformation in the Pahranagat area, southern Nevada, in Basin and Range Extensional Tectonics Near the Latitude of Las Vegas, Nevada, edited by B.P. Wernicke, Mem. Geol. Soc. Am., 176, 213. 236, 1990.

Jordan, T.E., B.L. Isacks, R.W. Allmendinger, J.A. Brewer, V.A. Ramos, and C.J. Ando, Andean tectonics related to geometry of subducted Nazca plate, Geol. Soc. Am. Bull., 94, 341-361, 1983.

Kellogg, H. E., Paleozoic stratigraphy of the southem Egan Range, Nevada, Geol. Soc. Am Bull., 74, 685-708, 1963.

Kley, J., Transition from basement-involved to thin-skinned thrusting in the Cordillera Oriental of southern Bolivia, Tectonics, 15 , 763-775, 1996.

Krogh, T. E., A low contamination method for hydrothermal decomposition of zircon and extraction of $\mathrm{U}$ and $\mathrm{Pb}$ for isotopic age determinations, Geochim. Cosmochim. Acta. 37, 485-494, 1973.

Krueger, H.W., and J.H. Schilling, Geochron/ Nevada Bureau of Mines K/Ar age determinations-List 1, Isochron West, 1, 9-14, 1971.

Lamb, S., and L. Hoke, Origin of the high plateau in the Central Andes, Bolivia, South America, Tectonics, 16, 623-649, 1997.

Lawson, A.C., The copper deposits of the Robinson mining district, Nevada, Dep of Geol. Bull. 4, pp. 287-357, Univ. of Calif. Publ. Geol. Sci, Berkeley, 1906.

Lawton, T.F., Compositional trends within a clastic wedge adjacent to a fold-thrust belt: Indianola Group, central Utah, in Foreland Basins, edited by P.A. Allen and P. Homewood, Spec Publ. Int. Assoc Sediment 8, 411-423, 1986.

Lawton, T.F., S.E. Boyer, and J.G. Schmitt, Influence of inherited taper on structural variability and conglomerate distribution, Cordilleran fold and thrust belt, western United States, Geology, 22, 339-342, 1994.

Lawton, T.F., D.A. Sprinkel, P.G. DeCelles, G. Mitra, A.J. Sussman, and M.P. Weiss, Stratigraphy and structure of the Sevier thrust belt and proximal foreland-basin system in central Utah: A transect from the Sevier Desert to the Wasatch Plateau, in Mesozoic to
Recent geology of Utah, edited by P.K. Link, and B.J. Kowallis, Brigham Young Univ. Geol. Stud., Part 2, 42, 33-67, 1997.

Lee, J., E.L. Miller, and J.F. Sutter, Ductile strain and metamorphism in an extensional tectonic setting: A case study from the northem Snake Range, Nevada, in Continental Extensional Tectonics, edited by M.P. Coward, J.F. Dewey, and P.L. Hancock, Geol. Soc. Spec. Publ. 28, 267-287, 1987.

Levy, M., and N. Christie-Blick, Pre-Mesozoic palinspastic reconstruction of the eastem Great Basin (westem United States), Science, 245, 1454-1462, 1989.

Longwell, C.R., E.H. Pampeyan, B. Bower, and R.J. Roberts, Geology and mineral deposits of Clark County, Nevada, Nev. Bur. Mines Bull., 62, 218 pp., 1965.

Ludwig, K.R., PBDAT for MS-DOS a computer program for IBM-PC compatibles for processing raw $\mathrm{Pb}-\mathrm{U}-\mathrm{Th}$ isotope data version 1.06, U S. Geol. Sur. Open File Rept, 88-542, 40, 1989.

Martin, M.W., Geology of the Worthington Mountains, Lincoln County, Nevada, M.S. thesis, 112 pp., Univ. of N.C., Chapel Hill, 1987.

Martin, M.W., and J.M. Bartley, Caldera collapse and normal faulting, Worthington Mountains, Lincoln County, Nevada, Geol. Soc. Am. Abstr. Programs, 2I, A111, 1989.

McGrew, A.J., The origin and evolution of the southern Snake Range decollement, eastcentral Nevada, Tectonics, 12, 21-34, 1993.

Miller, D.M., and T.D. Hoisch, Mesozoic structure, metamorphism, and magmatism in the Pilot Range and the Toano Ranges, in Field Guide to Geologic Excursions in Utah and Adjacent Areas of Nevada, Idaho, and Wyoming, edited by J.R. Wilson, Utah Geol. Surv. Misc. Publ., 92-3, 79-92, 1992.

Miller, D.M., and A.P. Lush, Geologic map of the Pilot Peak Quadrangle, Box Elder County, Utah, and Elko County, Nevada, Utah Geol Surv. Map, 160, 25 pp., 1994.

Miller, E.L., and P.B. Gans, Cretaceous crustal structure and metamorphism in the hinterland of the Sevier thrust belt, western U.S. Cordillera, Geology, 17, 59-62, 1989.

Miller, E.L., and P.B. Gans, Reply to comment on Cretaceous crustal structure and metamorphism in the hinterland of the Sevier thrust belt, western U.S. Cordillera, Geology, 18, 577, 1990.

Miller, E.L., P.B. Gans, and J. Garing, The Snake Range decollement: An exhumed mid-Tertiary ductile-brittle transition, Tectonics, 2, 239 263, 1983.

Miller, E.L., P.B. Gans, J.E. Wright, and J.F. Sutter, Metamorphic history of the east-central Basin and Range Province: Tectonic setting and relationship to magmatism, in Metamorphism and Crustal Evolution of the Western United States, Rubey Ser, vol. 7, edited by W.G. Ernst, pp. 649-682, PrenticeHall, Englewood Cliffs, N. J., 1988.

Misch, P., Regional structural reconnaissance in central-northeast Nevada and some adjacent areas: Observations and interpretations, Intermt. Assoc. Petrol. Geol., Annu. Field Conf., Guidebook, 11, 17-42, 1960.

Moores, E.M., R.B. Scott, and W.W. Lumsden, Tertiary tectonics of the White Pine-Grant Range region, east-central Nevada, and some regional implications, Geol. Soc. Am. Bull., 79, 1703-1726,1968.

Murray, M.E., Geology of the east-central Quinn Canyon Range, Nevada, M.S. thesis, 107 pp., Univ. of N. C., Chapel Hill, 1985.

Nelson, R.B., Comment on Cretaceous crustal structure and metamorphism in the hinterland of the Sevier thrust belt, western U.S. Cordillera, Geology, 18, 576-577, 1990.

Nolan, T.B., The underground geology of the Tonopah mining district, Nevada, Univ Nev. Bull, 29, 49 pp., 1935.

Nolan, T.B., The Eureka Mining District, Nevada, U.S. Geol. Surv Prof. Pap., 406, 1962.

Okaya, N., S. Tawackoli, and P. Giese, Areabalanced model of the late Cenozoic tectonic evolution of the central Andean arc and back arc (lat $20^{\circ}-22^{\circ} \mathrm{S}$ ), Geology, 25, 367-370, 1997.

Overtoom, G.J., Synvolcanic Oligocene stress reorientation in eastern Nevada: Evidence from the Golden Gate Range, M.S. thesis, 88 pp., Univ. of Utah, Salt Lake City, 1994.

Overtoom, G.J., and J.M. Bartley, Kinematic evidence for mid-Tertiary north-south extension across the western Blue Ribbon lineament, east-central Nevada, in Cenozoic Structure and Stratigraphy of Central Nevada 1996 Field Conference Volume, edited by W.J. Taylor and H. Langrock, pp. 35-43, Nev. Petrol. Soc., Reno, 1996.

Perry, W.J., Jr., Stratigraphy and structure of the northern Pancake Range, Nye County, Nevada: A progress report, in Some Current Research in Eastern Nevada and Western Utah by the U.S. Geological Survey, edited by C.H. Thorman, $U S$ Geol. Surv. Open File Rep., OF 91-0386, 6-7, 1991.

Perry, W.J., Jr., Structure of the northern Pancake Range, Nevada: A progress report, Geol. Soc. Am. Abstr. Programs, 24, 57, 1992.

Page, W.R., Low-angle normal faults in Devonian rocks of the southern Delamar Mountains, Lincoln County, Nevada, in Geologic Studies in the Basin and Range-Colorado Plateau Transition in Southeastern Nevada, Southwestern Utah, and Northwestern Arizona, edited by R.B. Scott and W.C. Swadley, U.S. Geol. Surv. Bull., 2056, 205-218, 1992.

Palmer, A.R., A proposed nomenclature for stages and series for the Cambrian of Laurentia, Can. J. Earth Sci., 35, 323-328, 1998.

Parrish, R. R., An improved micro-capsule for zircon dissolution in U-Pb geochronology, Chem. Geol., 66, 99-102, 1987.

Quinlivan, W.D., C.L. Rodgers, and H.W. Dodge Jr., Geologic map of the Portuguese Mountain Quadrangle, Nye County, Nevada, U.S. Geol. Surv. Misc. Invest. Map, I-804, 1974.

Reso, A., Composite columnar section of exposed Paleozoic and Cenozoic rocks in the Pahranagat Range, Lincoln County, Nevada, Geol. Soc. Am. Bull., 74, 901-918,1963.

Roeder, D., Thrust belt of central Nevada, Mesozoic compressional events, and the implications for petroleum prospecting, in Compressional and Extensional Structures in the Northern Basin and Range, edited by L.J. Garside and D.R. Shaddrick, pp. 21-29, Nev. Petrol. Soc., Reno, 1989.

Sainsbury, C.L., and F.J. Kleinhampl, Fluorite deposits of the Quinn Canyon Range, Nevada, U.S. Geol. Surv. Bull, 1272-C, 22 pp., 1969. Sargent, K.A., and F.N. Houser, The Shingle Pass 
tuff of central Nevada, Geol. Soc. Am. Abstr Programs, 2, 140-141, 1970.

Schmitz, M., A balanced model of the southern Central Andes, Tectonics, 13, 484-492, 1994.

Schwans, P., and K.M. Campion, Sequence architecture and stacking patterns in the Cretaceous foreland basin, Utah; tectonism versus eustasy, in Mesozoic to Recent Geology of Utah, edited by P.K. Link, and B.J. Kowallis, Brigham Young Univ. Geol. Stud., Part 2, 42, 105-134, 1997.

Sheffels, B.M., Lower bound on the amount of crustal shortening in the central Bolivian Andes, Geology, 18, 812-815, 1990.

Smith, D.L., E.L. Miller, S.J. Wyld, and J.E. Wright, Progression and timing of Mesozoic crustal shortening in the northern Great Basin, western U.S.A., in Mesozoic Paleogeography of the Western United States - II, edited by G.C. Dunne and K.A. McDougall, vol. 71, pp. 389-405, Soc. Econ. Paleontol. Mineral, Pac Sect., Los Angeles, 1993.

Speed, R.C., Evolution of the sialic margin in the central-western United States, in Studies in Continental Margin Geology, edited by J.S. Watkins and C.L. Drake, AAPG Mem. 34, 457-468,1983.

Speed, R.C., M.W. Elison, and F.R. Heck, Phanerozoic tectonic evolution of the Great Basin, in Metamorphism and Crustal Evolution of the Western United States, Rubey Ser., vol. 7, edited by G. Emst, pp. 572-605, Prentice-Hall, Englewood Cliffs, N. J., 1988.

Stacey, J.S., and J.D. Kramers, J. D., Approximation of terrestrial lead isotope evolution by a two-stage model, Earth Planet. Sci. Lett., 26, 207-221, 1975.

Steele, G., Pennsylvanian-Permian stratigraphy of east-central Nevada and adjacent Utah, in Guidebook to the Geology of East-Central Nevada, pp. 91-113, Intermountain Assoc. Petrol. Geol., Salt Lake City, Utah, 1960.

Steiger, R. H., and E. Jäeger, Subcommission on geochronology convention on the use of decay constants in geo- and cosmochronology, Earth Planet. Sci Lett., 36, 359-362, 1977.

Stewart, J.H., J.R. MacMillan, K.M. Nichols, and C.H. Stevens, Deep-water upper Paleozoic rocks in north-central Nevada: A study of the type area of the Havallah Formation, in Paleozoic Palegeography of the Western United States: Pacific Coast Paleogeography Symposium I, edited by J.H. Stewart, C.H. Stevens, and A.E. Fritsche, pp. 337-347, Soc. Econ. Paleontol. Mineral., Los Angeles, Calif., 1977.

Taylor, W.J., Spatial and temporal relations of Cenozoic volcanism and extension in the North Pahroc and Seaman Ranges, eastern Nevada, in Basin and Range Extensional
Tectonics Near the Latitude of Las Vegas, Nevada, edited by B.P. Wernicke, Mem Geol Soc. Am., 176, 181-193, 1990.

Taylor, W.J., Structural patterns and crustal evolution during extension in the southem Great Basin, Eos Trans. AGU, 73(43), 548, 1992.

Taylor, W.J., and J.M. Bartley, Prevolcanic extensional breakaway fault, White River Valley, Nevada, and regional implications, Geol Soc. Am. Bull, 104, 255-266, 1992.

Taylor, W.J., J.M. Bartley, D.R. Lux, and G.J. Axen, Timing of Tertiary extension in the Railroad Valley-Pioche Transect, Nevada: Constraints from ${ }^{40} \mathrm{Ar} r^{39} \mathrm{Ar}$ ages of volcanic rocks, J. Geophys. Res., 94, 7757-7774, 1989.

Taylor, W.J., S.W. Dobbs, S.L. Nelson, and P.A Armstrong, Generation of four-way closure through multiple tectonic events: Structures of the Timpahute Range, Southern Nevada; in Structural and Stratigraphic Investigations and Petroleum Potential of Nevada, with Special Emphasis South of the Railroad Valley Producing Trend, 1994 Field Conf., vol. II, edited by S.W. Dobbs and W.J. Taylor, pp. 141-156, Nev. Petrol. Soc., Reno, 1994.

Taylor, W.J., J.M. Bartley, J.E. Fryxell, J. Schmitt, and D.S. Vandervoort, Mesozoic Central Nevada thrust belt, in Crustal Evolution of the Great Basin and the Sierra Nevada, Cordilleran/Rocky Mountain Sect. Field Trip Guidebook, edited by M.M Lahren, J.H. Trexler, and C. Spinosa, pp. $57-$ 96, Geol. Soc. of Am., Boulder, Colo., 1993.

Tschanz, C.M., and E.H. Pampeyan, Geology and mineral deposits of Lincoln County, Nevada, Nev. Bur. Mines Geol. Bull., 73, 188 pp., 1970.

Vandervoort, D.S., and J.G. Schmitt, Cretaceous to early Tertiary paleogeography in the hinterland of the Sevier thrust belt, eastcentral Nevada, Geology, 18, 567-570, 1990.

Walker. J.D., B.C. Burchfiel, and G.A. Davis, New age controls on initiation and timing of foreland belt thrusting in the Clark Mountains, southern California, Geol. Soc. Am. Bull., 107, 742-750, 1995.

Wannamaker, P.E., J.M. Johnston, J.A. Stodt, and J.R. Booker, Anatomy of the southern Cordilleran hingeline, Utah and Nevada, from deep electrical resistivity profiling, Geophysics, 62, 1069-1086, 1997.

Wells, M.L., Alternating contraction and extension in the hinterlands of orogenic belts: An example from the Raft River Mountains, Utah, Geol. Soc. Am. Bull., 109, 107-126, 1997.

Wells, M.L., R.D. Dallmeyer, and R.W. Allmendinger, Late Cretaceous extension in the hinterland of the Sevier thrust belt, northwestern Utah and southern Idaho, Geology, $18,929-933,1990$.
Wernicke, B., and B.C. Burchfiel, Modes of extensional tectonics, J. Struct. Geol., 4, 105$115,1982$.

Wernicke, B.P., P.L. Guth, and G.J. Axen, Tertiary extensional tectonics in the Sevier thrust belt of southem Nevada, in Western Geological Excursions 4, edited by J.P. Lintz, pp. 473-510, Mackay School of Mines, Reno, 1984.

Wernicke, B., G.J. Axen, and J.K. Snow, Basin and Range extensional tectonics at the latitude of Las Vegas, Nevada, Geol. Soc. Am. Bull., 100, 1738-1757, 1988a.

Wernicke, B., J.K. Snow, and J.D. Walker, Correlation of Mesozoic thrusts in the southern Great Basin and their possible indication of 250-300 km of Neogene crustal extension, in This Extended Land Geological Journeys in the Southern Great Basin, Cordilleran Sect. Field Trip Guide, edited by D.L. Weide and M.L. Faber, pp. 255-269, Geol. Soc. of Am., Boulder, Colo., 1988b.

Woodward, N.B., S.E. Boyer and J. Suppe, An outline of balanced cross sections, Studies in Geol., 11, 170 pp., Univ. of Tenn., Knoxville, 1985.

P.A. Armstrong, Department of Geological Sciences, California State University, Fullerton, P.O. Box 6850, Fullerton, 92834-6850 CA. (parmstrong@fullerton.edu)

J.M. Bartley, Department of Geology and Geophysics, University of Utah, $135 \mathrm{~S} 1460 \mathrm{E}$, Rm. 719, Salt Lake City, UT 84112-0111Salt Lake City, UT. (jbartley@mines.utah.edu)

J.E. Fryxell, Department of Geological Sciences, Califomia State University, San Bernardino, 5500 University Parkway, San Bernardino, CA, 92407. (jfryxell@csusb.edu)

J.W. Geissman, Department of Earth and Planetary Sciences, University of New Mexico, Albuquerque, $\quad \mathrm{NM}, \quad$ 87131-1116. (jgeiss@unm.edu)

M.W. Martin, U-Pb Geochronology Laboratory, Massachusetts Institute of Technology, Cambridge, MA. (mwm@MIT.EDU)

W.J. Taylor, Department of Geoscience, University of Nevada, Las Vegas, 4505 Maryland Parkway, Las Vegas, NV 89154-4010. (wjt@nevada.edu)

J.D. Walker, Department of Geology, 120 Lindley Hall, University of Kansas, Lawrence, KS 66045-2124. (jdwalker@ukans.edu)

(Received June 21, 1999; revised March 31, 2000; accepted June 16, 2000.) 